\title{
THE MURCHISON GREENSTONE BELT, SOUTH AFRICA: ACCRETED SLIVERS WITH CONTRASTING METAMORPHIC CONDITIONS
}

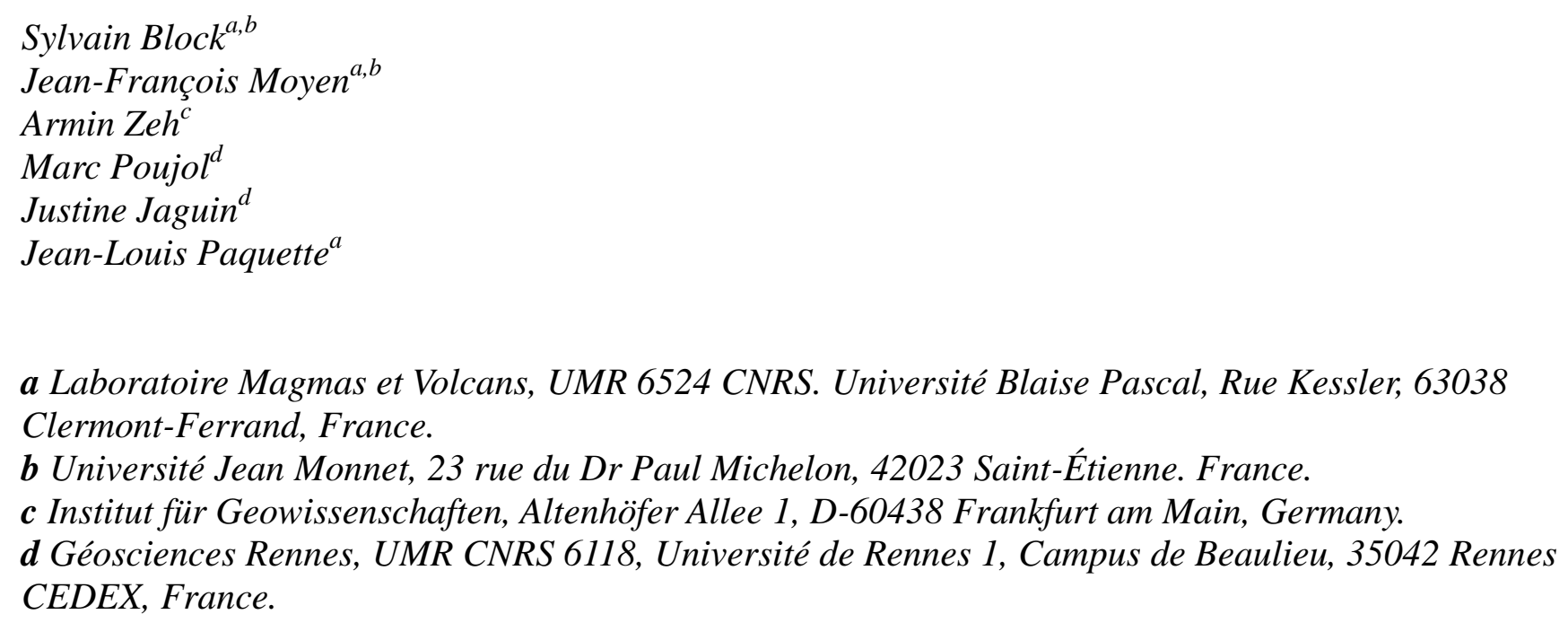

\section{Abstract}

This paper presents new petrological and geochronological data for the $\sim 3.09-2.92$ Ga Murchison

31 Greenstone Belt (MGB), located in South Africa's Kaapvaal Craton, and discusses their geotectonic implications. The MGB is made of three tectono-metamorphic units: the Silwana Amphibolites, the Murchison Unit and the La France Formation. They underwent contrasting clockwise pressuretemperature-deformation (P-T-D) histories, and are separated from each other by relatively narrow, highstrain shear zones, with a sinistral, transpressive top-to-the-south movement, consistent with the deformation patterns observed throughout the belt. These patterns are explained by a N-S compressional stress field, affecting the Murchison Belt between 2.97 and $2.92 \mathrm{Ga}$. Results of new petrological investigations indicate that ultramafic to felsic volcano-sedimentary rocks of the Murchison Unit underwent a greenschist- to lower-amphibolite-facies metamorphism at maximum $\mathrm{P}-\mathrm{T}$ conditions of 5.6 
$40 \pm 0.6 \mathrm{kbar}$ at $570^{\circ} \mathrm{C}$, along a relatively hot, minimum apparent geotherm of $\sim 30^{\circ} \mathrm{C} / \mathrm{km}$. In contrast, the 41 Silwana Amphibolites and the La France Formation were metamorphosed at much higher peak 42 metamorphic conditions of 8.7-10 kbar, 630-670 $\mathrm{C}$, and 8-9 kbar, $600-650{ }^{\circ} \mathrm{C}$ respectively, and require a 43 colder apparent geotherm of $\sim 20^{\circ} \mathrm{C} / \mathrm{km}$. A retrograde, nearly isothermal-decompression $\mathrm{P}-\mathrm{T}$ path 44 followed by isobaric cooling is also inferred for the La France Formation. The timing of the structural45 metamorphic overprint is bracketed between 2.97 and $2.90 \mathrm{Ga}$, which is constrained by U-Pb zircon ages 46 of a syn-deformation granite within the Murchison Unit and the post-deformation Maranda granite, 47 respectively. Monazite and xenotime from La France metapelites yield much younger ages of ca. $2.75 \mathrm{Ga}$, 48 with few inherited components at $2.92 \mathrm{Ga}$. They point to a later activation of the MGB, perhaps related with tectono-thermal events in the Rooiwater Complex and the Pietersburg Greenstone Belt. The relatively cold apparent geotherms recorded in the Silwana and La France rocks, the contrasted peak P$\mathrm{T}$ conditions between the different units, and the near isothermal decompression of the La France Formation indicate that the Kaapvaal craton crust must have been cold enough to enable significant crustal thickening and strain localisation along narrow shear zones and, as a consequence, fast tectonic juxtaposition of rocks metamorphosed at different crustal depths. These features are similar to those observed along Palaeozoic or modern day, oblique subduction-collision zones, but different to those of hot Archaean provinces. We therefore interpret the MGB as representing part of an oblique collision-zone between two terrains of the Kaapvaal craton: the Witwatersrand and Pietersburg terrains.

Keywords : Metamorphism, Archaean tectonics, Murchison Greenstone Belt, Kaapvaal craton.

\section{Introduction}

Many tectonic studies on various Archaean cratons have reported structural features in volcanosedimentary belts that differ from younger Proterozoic and Phanerozoic orogenic belts (e.g. Bouhallier et 
al., 1993, 1995; Choukroune et al., 1995, 1997; Chardon et al., 1996, 1998, 1999). Linear fold and thrust belts, strain localisation along crustal scale faults, juxtaposition of contrasted metamorphic domains forming "paired metamorphic belts" (e.g., the Mesozoic Ryoke-Sanbagawa belts in Japan, Miyashiro, 1961; Brown, 2010 and references therein), tectonically driven exhumation processes, as well as features that are typical of subduction, such as ophiolites, accretionary prisms and blueschist-facies to Ultra-HighPressure-facies metamorphism, are widely recognised in modern orogens. On the other hand, ubiquitous craton scale shear zones, dome and basin strain patterns, deformation distribution on a regional scale, and the relative homogeneity of erosion levels and metamorphic gradients are characteristic of many Archaean granite-greenstone provinces (Binns et al., 1976; Park, 1992; Chardon et al., 2008, 2009). The description of features in Archaean provinces interpreted to be related to subduction and modern-style accretion tectonics has fed the debate on the onset of plate tectonics and on the evolution of tectonic regimes through time (e.g. Komiya et al., 1999; Kusky et al., 2001; de Wit, 2004; Condie and Kröner, 2008; Cawood et al., 2009); and the recognition of contrasted tectono-metamorphic signatures between modern and Archaean orogens led authors to invoke secular changes in the thermal regime of the Earth as the factor driving the shift from one tectonic style to another (e.g. Komiya et al., 2002; Brown, 2007; Gapais et al, 2009; Sizova et al., 2010). A wide range of models were proposed to account for the features observed in Archaean provinces. An intellectual framework defined by two "end-member" models, with a hot and weak lithosphere in the Archaean as opposed to a cold and strong lithosphere in the Proterozoic and Phanerozoic eras has been widely adopted. However, given the wide variation in the rheological properties of Phanerozoic lithospheres (Watts and Burov, 2003 and refs. therein), one can expect to be confronted to such geographical disparities in Archaean cratons.

The heat budget of the lithosphere is a major control of its rheological properties, and as a consequence, of the dominant tectonic regime in the crust. Metamorphic rocks record evidence of the pressure and temperature evolution with time, which reflects the thermal environment under which the constituent mineral assemblages equilibrated. Spatial distribution of peak $\mathrm{P}-\mathrm{T}$ conditions provide information on the spatial variation in thermal regimes; hence metamorphic studies are an important tool to investigate the 
tectonic style of Archaean provinces. Although metamorphic studies, coupled with structural and geochronological constraints, have contributed greatly to our understanding of modern orogenic processes (e.g. Miyashiro, 1961; Ernst, 1973, 1975, 1988; Chopin, 1984; Smith, 1984; Brown, 2009), metamorphism across Archaean granite-greenstone terrains has been comparatively under-studied. Consequently, the lack of well-constrained metamorphic studies has hampered the development of a geodynamic framework for the formation of granite-greenstone terrains. It has also led to the generalisation in the literature of implicit assumptions on Archaean metamorphism, as some observations relevant to specific Archaean provinces are taken to be a general rule.

Most granite-greenstone terrains are reported to have undergone metamorphism along high-Temperature, low-Pressure apparent geothermal gradients. Metamorphic conditions are generally described as isobaric across hundreds of kilometres, with isotherms parallel to the surface, or as grading progressively from low-grade greenschist-facies to granulite-facies across kilometres-large and hundreds of kilometres-long shear zones, where strain is distributed rather than localised (Grambling, 1986; Collins and Vernon, 1991; Percival et al.,1992; Percival et al., 1994; Caby et al., 2000). Variations in metamorphic grade in Archaean granite-greenstone terrains are frequently attributed to contact metamorphism linked to the emplacement of granitoid bodies, or as the result of a "crustal overturn" (Van Kranendonk, 2002). However, an increasing number of studies provide evidence for disparities in metamorphic patterns between Archaean terrains. High P-low T metamorphism $\left(18-20 \mathrm{kbar}, 630^{\circ} \mathrm{C}\right)$ is reported from the Indian Bundelkhand Craton at ca. $2.78 \mathrm{Ga}$ (Saha et al., 2011); ca. $2.72 \mathrm{Ga}$ eclogite-facies metamorphism is recorded in the Belomorian belt of Russia (Volodichev, 2004; Brown, 2009; Mints et al., 2010). High metamorphic gradients between terrains metamorphosed at different depths, and juxtaposed along planar tectonic structures that localised deformation, are described in the Palaeoarchaean Barberton Greenstone Belt (BGB), in the east of the Kaapvaal craton, South Africa (Kisters et al., 2003; Diener et al., 2005; Moyen, 2006) and in the Mesoarchaean Point Lake orogen of the Slave Province, Canada ( Kusky et al. 1991).

This study aims to unravel the tectono-thermal history of the northwestern part of the Archaean Kaapvaal Craton in South Africa. In order to do so, the metamorphic conditions across the Murchison 
118 Greenstone Belt, the nature of the contacts between the distinct tectono-metamorphic units, and the 119 timing of the structural-metamorphic and magmatic processes were investigated. By coupling the 120 different information, we intend to bring new insights into the geodynamic evolution that led to the 121 formation of the MGB and to contribute to a broader understanding of Archaean tectonics.

\section{Geological setting of the MGB}

\subsection{Regional context and geochronological constraints}

The ENE-WSW trending Murchison Greenstone Belt is one of the volcano-sedimentary belts of the Archaean Kaapvaal craton of South Africa (Brandl et al., 2006; Robb et al., 2006) (Fig. 1). It is situated about 200 km north of the ca. 3.5-3.2 Ga Barberton Greenstone Belt (e.g. Kröner et al., 1991, 1992, 1996; Kamo and Davis, 1994; Dziggel et al., 2002), and about $80 \mathrm{~km}$ south of the 3.2-2.8 Ga Giyani Greenstone Belt (Kröner et al, 2000). It extents for $140 \mathrm{~km} \mathrm{ENE-WSW,} 15-20 \mathrm{~km} \mathrm{~N}-\mathrm{S}$, and is unconformably overlain by the Neoarchaean to Palaeoproterozoic sediments of the Transvaal Supergroup (Burger and Coertze, 1973; Altermann and Nelson, 1998) at its western extremity. Furthermore, it is located along the "Murchison-Thabazimbi Lineament" (Du Plessis, 1990), which is defined on the basis of geophysical data and interpreted to form an important terrain boundary in the northern Kaapvaal craton, separating the Witwatersrand terrain to the south from the Pietersburg terrain to the north (Good and de Wit, 1997; Anhaeusser, 2006, Zeh et al., 2009). 


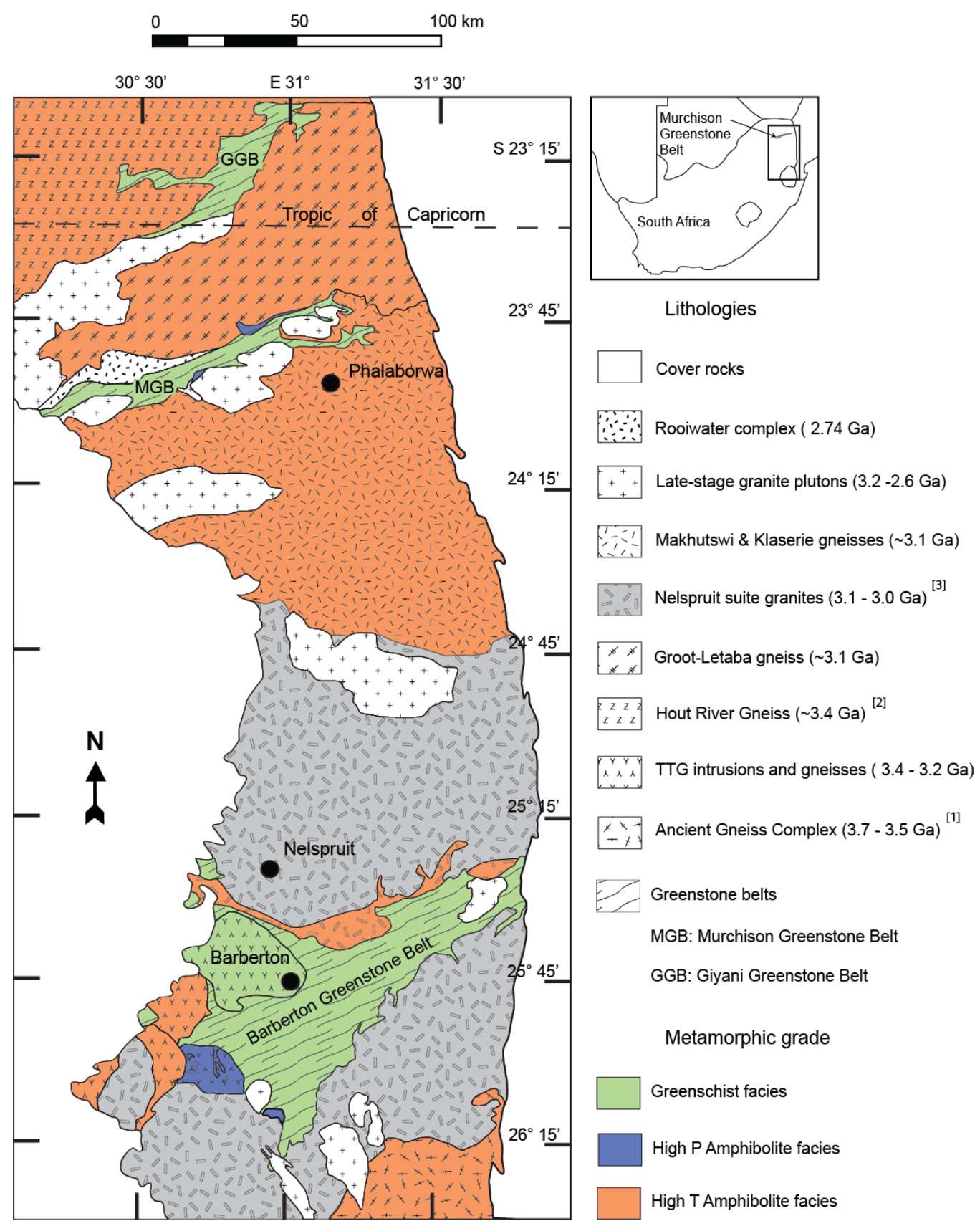

140 Figure 1:

141 Simplified geologic map of the north-eastern part of the Kaapvaal craton. Different colours represent domains with different metamorphic grades, inferred from sparse field observations and data from the literature. [1]: Kröner and Tegtmeyer (1994); Compston and Kröner (1988), [2]: Kamo and Davis (1994), [3]: Brandl and Kröner (1993); Kröner et al. (2000). See text for other references.

At its northern margin, the supracrustal rocks of the MGB are bounded by the Rooiwater Complex and the Groot Letaba Gneisses. The Rooiwater Complex (Vearncombe et al., 1997) represents a mostly undeformed layered mafic intrusion emplaced at a minimum age of $2.74 \mathrm{Ga}$ (Poujol et al. 1996) and 
149 subsequently intruded by mafic dykes at $2.61 \mathrm{Ga}$ (Zeh et al., 2009). Field evidence however suggest that 150 this age may correspond to a late resetting of geochronometers, and the emplacement age of the 151 Rooiwater complex is likely to be significantly older (Vearncombe, 1992). The contact between the 152 Rooiwater Complex and the MGB is tectonically reworked (Vearncombe, 1992). The Groot Letaba 153 Gneisses (Brandl and Kröner, 1993) comprise a series of locally migmatised dark-grey gneisses, tonalites 154 and trondjhemites. They were mostly emplaced at ca. $3180-3000 \mathrm{Ma}$, with the exception of some ca. $1552885 \pm 4$ Ma discordant leucogneisses (Brandl and Kröner, 1993). The basement directly to the south of 156 the MGB is made of granitoids (TTGs) of the French Bob's Mine, emplaced $3228 \pm 12$ Ma ago (Poujol et 157 al. 1996); and by younger intrusive granitoids of ca. 3110 - 3060 Ma (Brandl and Kröner, 1993 ; Poujol 158 and Robb, 1999). The southern margin of the MGB was affected by the episodic intrusion of granite plutons and pegmatites of the Voster Suite, at ca. 3020, 2970, 2900, 2820 and 2680 Ma, respectively for the Baderoukwe, Discovery, Maranda, Willie, Mashishimale plutons, and associated intrusions (Fig. 2) (Poujol et al 1996; Poujol and Robb, 1999; Poujol, 2001; Zeh et al., 2009). Published geochronological data indicate that the supracrustal sequence of the MGB formed over a period of more than $100 \mathrm{Ma}$, between ca. 3090 and 2970 Ma (Poujol et al., 1996, Poujol et al., 2001). 

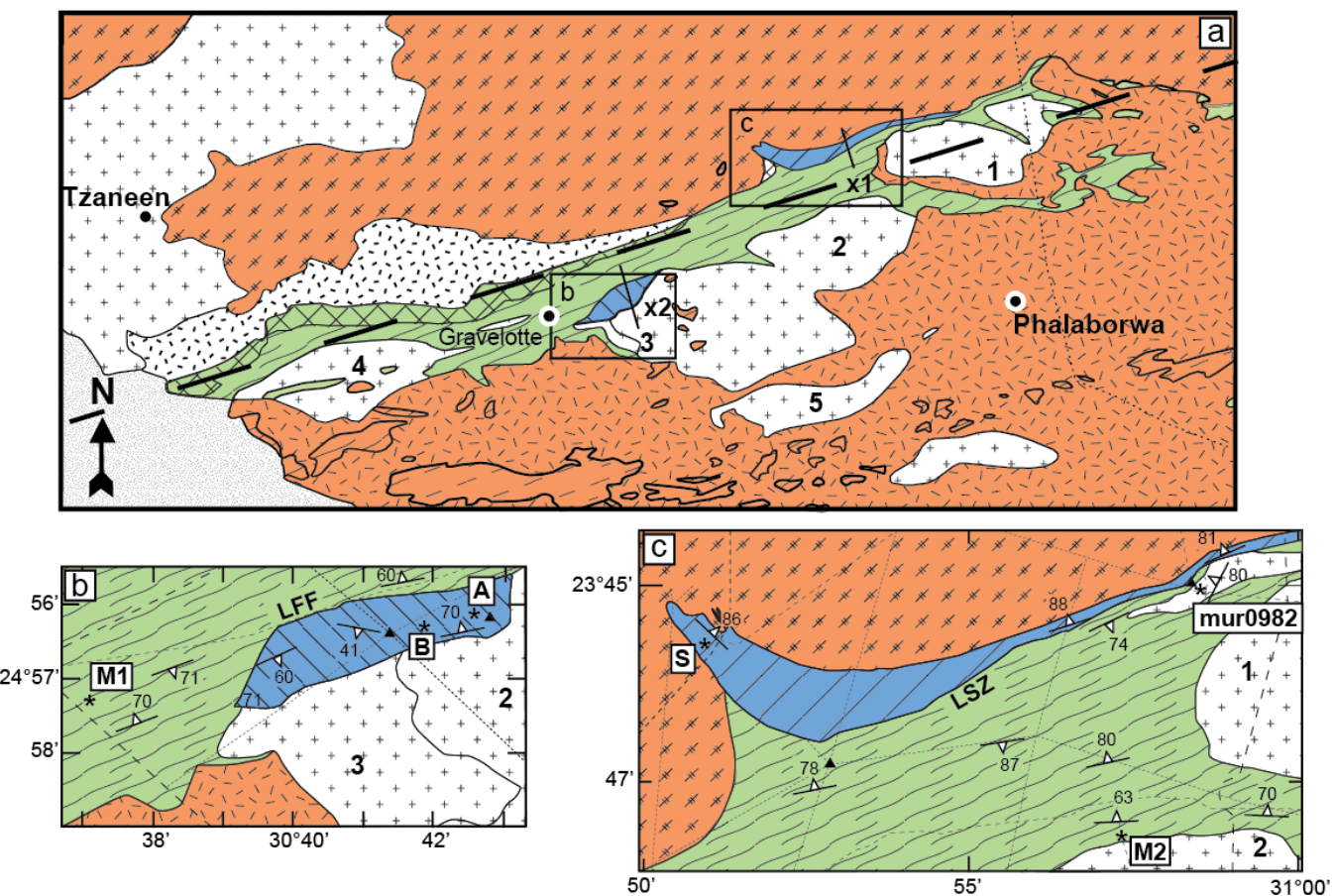

Lithologies

Metamorphic grade

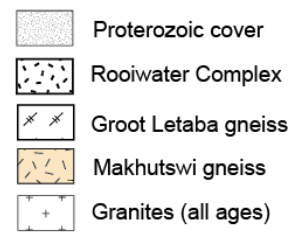

1 Baderoukwe granodiorite

2 Lekkersmaak suite

3 Willie granite

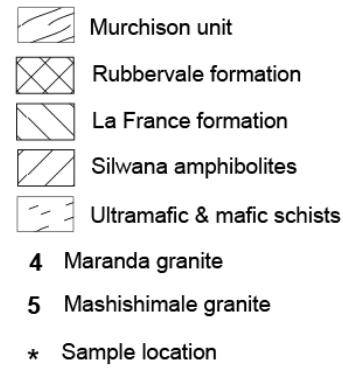

* Sample location

- $\quad$ Murchison - Thabazimbi Lineament

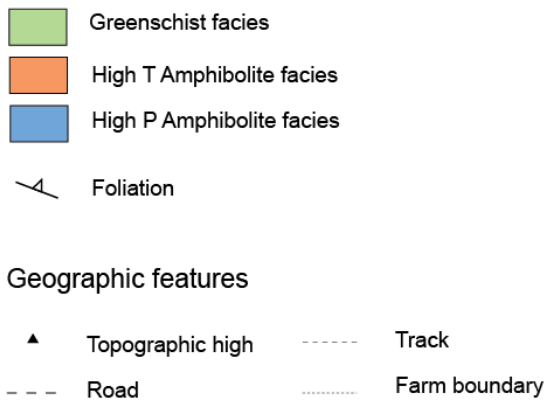

Figure 2:

(a) Simplified geologic and metamorphic map of the Murchison Greenstone Belt and its surroundings. (b,

c) Detailed maps with the location of samples (A, B, S, M1, M2 and mur0982) discussed in the text, modified from Vearncombe et al. (1992). The lines marked with $x_{1}$ and $x_{2}$ correspond to the cross section shown in Fig. 9. $L F F=$ La France Fault, LSZ = Letaba Shear Zone.

\subsection{Structural-Metamorphic Units of the MGB}

Based on structural and lithological criteria, Vearncombe et al. (1992) subdivided the MGB into four major, ENE-WSW-striking lithostratigraphic domains (Fig. 2): 

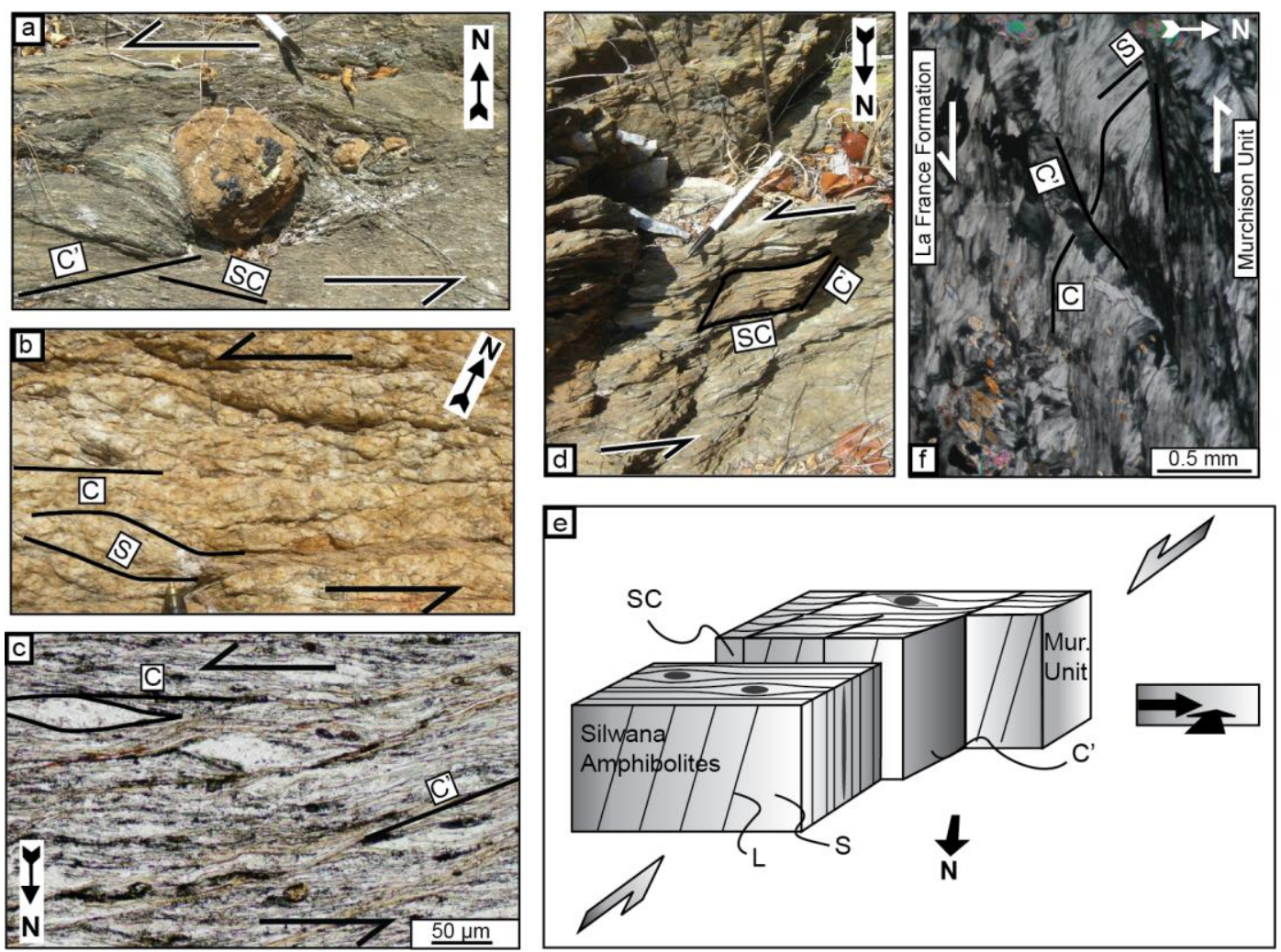

Figure 3:

Fabrics at or near to the sheared contacts between the different terrains of the MGB. (a). Asymmetric pressure shadow zones around a carbonate nodule in a mylonitic carbonate schists of the Murchison Unit, in the Letaba Shear Zone. (b) S-C fabrics in a deformed granite within the Letaba Shear Zone. (c) Microstructures observed in the quartz-chlorite schists of the Letaba Shear Zone include C'shear bands and mineral fish. (d) $S$-C - $C^{\prime}$ planes in quartz-chlorite schists of the Murchison Unit, in the Letaba Shear Zone. The kinematic indicators in $(a),(b),(c)$ and $(d)$ provide evidence for sinistral motion along the shear zone. (e) Synopsis of the structures observed along the Letaba shear zone. The flattening fabric in the Silwana amphibolites, that formed under upper- amphibolite facies conditions, occurs in close contact with mylonitised schists of the Murchison Unit, which provide evidence for a sinistral strike-slip under greenschist facies conditions. The latter is interpreted to have occurred in a transpressive setting and was accompanied by a top-to-the-south motion. (f) $S-C-C^{\prime}$ fabrics in a chlorite schists of the Murchison Unit, near the contact with the La France Formation, provide evidence for top-to-the-south motion. The C planes are subvertical.

The largest lithological domain of the MGB, hereafter referred to as the "Murchison Unit", includes the MacKop, Weigel, Leydsdorp and Mulati formations of the South African Committee for Stratigraphy (SACS) (1980) nomenclature. It consists of mafic and ultramafic volcanic rocks along with volcano- 
sedimentary and sedimentary rocks. The most representative lithologies of the domain are mafic quartz196 chlorite and albite-chlorite-actinolite schists, locally pillowed. The volcano-sedimentary rocks are locally interbedded with BIFs and with aluminous quartzites and conglomerates. The clastic sediments form prominent ridges, often corresponding to synform limbs in the central part of the MGB. Massive carbonates and carbonate schists crop out mostly along a high-strain shear zone in the centre of the belt, flanked by quartzite ridges to the north: the Antimony Line (Viljoen et al., 1978; Vearncombe, 1988a, 1992), which hosts $\mathrm{Sb}( \pm \mathrm{Au})$ mineralisation. Serpentinite lenses occur in the southern part of the belt.

Stratigraphic relationships within this unit remain unclear, as contacts between formations are tectonic in nature (Vearncombe, 1992). U-Pb zircon ages provide evidence that the Weigel Formation volcanics were emplaced at ca. $3.09 \mathrm{Ga}$, while a maximum age of deposition for the MacKop conglomerate was found to be ca. 3.08 Ga old (Poujol et al., 1996).

The Rubbervale Formation is exposed along the northwestern flank of the MGB. It comprises quartzporphyroclastic schists, along with felsic lavas, tuffs and breccias. This formation also hosts the major VMS-type deposit of the so-called 'Cu-Zn" line (Schwarz-Schampera et al., 2010). Emplacement of the Rubbervale formation was dated at ca. 2.97 Ga (Brandl et al. 1996 ; Poujol et al. 1996 ; Poujol 2001).

The third unit, the Silwana Amphibolites (Vearncombe et al., 1992; part of the Rubbervale formation in the SACS terminology), is exposed in the north-eastern part of the MGB, and represent a 0.1-1.5 km wide 213 sliver of amphibolites, rarely garnet-bearing, displaying a centimetric layering.

214 La France Formation (Vearncombe et al., 1992, SACS terminology) mostly consists of quartzite and 215 kyanite- staurolite- garnet-bearing biotite micaschists.

217 Vearncombe et al. (1988b) and Vearncombe (1992) stated that the Silwana Amphibolites and the rocks of 218 the La France Formations experienced a higher degree of metamorphism than the rocks of the Murchison 219 Unit and Rubbervale Formation, which together form the core of the MGB (Fig. 2). Metamorphic P-T conditions were estimated to be $>5 \mathrm{kbar}, 550-650^{\circ} \mathrm{C}$ for the La France Formation, while field 
observations qualitatively suggested a higher grade metamorphic conditions in the Silwana Amphibolites compared to the Murchison Unit.

Table 1:

225 Summary of the mineral assemblages and textures developed in the different formations of the MGB.

\begin{tabular}{|c|c|c|c|c|c|}
\hline Terrain & Rock type & Outcrop occurrence & Mineral assemblages & Texture & Sample \\
\hline $\begin{array}{l}\text { La France } \\
\text { Formation }\end{array}$ & $\begin{array}{l}\text { Gt- St- } \\
\text { bearing } \\
\text { micaschist }\end{array}$ & $\begin{array}{l}\text { Bt-schist with thin } \\
\text { metamorphic banding, } \\
\text { crenulated. Protruding } \\
\text { elongated Gt and St }\end{array}$ & $\begin{array}{c}\text { Peak }\left(\text { syn- } D_{2}\right): G t+S t+B t+ \\
M s+Q \\
\text { Post-peak: Bt, Hem }\end{array}$ & $\begin{array}{l}\text { Large Gt and St } \\
\text { porphyroblasts, thin Bt } \\
\text { beds, crenulated. }\end{array}$ & A \\
\hline $\begin{array}{l}\text { La France } \\
\text { Formation }\end{array}$ & $\begin{array}{l}\text { Ky }( \pm S t)- \\
\text { bearing } \\
\text { micaschist }\end{array}$ & $\begin{array}{l}\text { Bt-schist with thin } \\
\text { metamorphic banding. } \\
\text { Protruding elongated Ky. }\end{array}$ & $\begin{array}{c}\text { Peak }\left(\text { syn- } \mathrm{D}_{2}\right): \mathrm{Ky}+\mathrm{Bt}+\mathrm{Ms}+ \\
\mathrm{Pl} \pm \mathrm{St} \pm \mathrm{Ilm} \pm \mathrm{Ru}+\mathrm{Q} \\
\text { Retrograde: } \mathrm{Bt}+\mathrm{Sill}+\mathrm{Pl}+\mathrm{Crd} \\
/ \mathrm{Bt}+\mathrm{Chl}+\mathrm{Ms}+\mathrm{St} \pm \mathrm{Ky} \\
\text { Accessory : Mnz, Xno }\end{array}$ & $\begin{array}{l}\text { Large Ky porphyroblasts, } \\
\text { elongated parallel to } \mathrm{Bt} \\
\text { beds. Retrograde Crd, Bt - } \\
\text { Chl - Ms simplectite, St }\end{array}$ & B \\
\hline $\begin{array}{l}\text { Murchison } \\
\text { Unit }\end{array}$ & $\begin{array}{l}\text { Act-bearing } \\
\text { metabasite }\end{array}$ & $\begin{array}{l}\text { Green metabasite, no } \\
\text { pervasive tectonic fabric }\end{array}$ & $\begin{array}{c}\text { Peak : Act }+ \text { Ab }+C h l+E p+ \\
\text { Sph }\end{array}$ & $\begin{array}{l}\text { Garbenscheifer texture: } \\
\text { needle-shaped Act, Chl in } \\
\text { late shear bands }\end{array}$ & M1 \\
\hline $\begin{array}{c}\text { Murchison } \\
\text { Unit }\end{array}$ & $\begin{array}{l}\text { Aluminous } \\
\text { quartzite }\end{array}$ & $\begin{array}{c}\text { Fine grained quartzite } \\
\text { with well developped } \\
\text { metamorphic cleavage, } \\
\text { parallel to micaceous } \\
\text { bedding } \\
\end{array}$ & $\begin{array}{l}\text { Peak : } \mathrm{Gt}+\mathrm{Bt}+\mathrm{Ms}+\mathrm{Q} \\
\quad \text { Retrograde: } \mathrm{Chl}\end{array}$ & $\begin{array}{l}\text { Thin aligned Ms and } \mathrm{Bt} \\
\text { beds with small Gt, } \\
\text { intercalated with } \\
\text { protogranular quartz beds }\end{array}$ & M2 \\
\hline $\begin{array}{c}\text { Silwana } \\
\text { Amphibolites }\end{array}$ & $\begin{array}{l}\text { Gt- Hbl- } \\
\text { bearing } \\
\text { amphibolite }\end{array}$ & $\begin{array}{c}\text { Dark, fine grained, } \\
\text { massive « amphibolitic } \\
\text { gneiss » with occasional } \\
\text { garnet-bearing layers. }\end{array}$ & $\begin{array}{c}\text { Peak: } \mathrm{Hbl}+\mathrm{Pl}+\mathrm{Gt}+\mathrm{Bt}+\mathrm{IIm} \\
+\mathrm{Q} \\
\text { Retrograde: Chl, Ep } \\
\text { Accessory: Ap, Calc }\end{array}$ & $\begin{array}{l}\text { Equigranular texture with } \\
\text { aligned Hbl. Intercalation of } \\
\mathrm{Hbl} \text { and recristallised PI } \\
\text { and quartz beds. Gt } \\
\text { porphyroblasts with Ilm and } \\
\text { Hbl inclusions }\end{array}$ & S \\
\hline
\end{tabular}

\subsection{Contact zones between the units of the MGB}

The different units of the MGB are separated from each other by large-scale ductile shear zones. A detailed structural study of the MGB is beyond the scope of this paper and only a brief review of the nature of the contacts is presented here. A description of the regional strain field and the tectonics of the MGB are given in Vearncombe (1988b); Kusky and Vearncombe (1997) and Jaguin et al. (2012). 
238 To the north-east of the MGB, the Letaba Shear Zone (LSZ) separates the Silwana Amphibolites from 239 low-grade, quartz-chlorite and carbonate schists of the Murchison Unit. The contact is very sharp and 240 shows signs of a tectonic melange. The Silwana Amphibolites display a penetrative flattening fabric 241 formed under amphibolite-facies conditions. The cleavage is subvertical and bears a steep (pitch $>75^{\circ}$ ) 242 easterly plunging mineral elongation lineation. Asymmetric shear sense indicators are rare within this 243 formation: pressure shadow zones around garnet porphyroblasts are symmetrical, and no shear bands 244 were observed in thin sections. Towards the contact with the Silwana Amphibolites, the Murchison Unit 245 schists display a mylonitic microstructure and a significant grain size reduction. The mylonites exhibit an 246 NE-SW cleavage, parallel to the contact between the two formations. The cleavage has a moderate to subvertical dip to the south and carries a mineral elongation lineation dipping moderately (pitch $>40^{\circ}$ ) to the east. Asymmetric shear sense indicators, such as pressure shadow zones around primary carbonate nodules consistently point to a sinistral shear (Fig. 3a). The same shear direction is also reflected by SCC'-fabrics and extensional crenulation cleavages (Berthé at al., 1979; Platt and Vissers, 1980), indicative of stretching parallel to the foliation, which are well developed within the mylonitised quartz-chloriteschists (Fig. 3c, d). At the "Witkop" locality (near sample mur0982 in Fig. 2), where the relationships between the different units are clearly exposed, a deformed granite intrudes the greenschist-facies mylonites of the Murchison Unit. No contact metamorphism was observed in the quartz-chlorite schists Amphibolites. 
265 The La France Formation is separated from the greenschist-facies rocks of the Murchison Unit by a 266 highly deformed zone a few dozen metres wide, hereafter named the "La France Fault". The lithologies in 267 contact with the northern boundary of the La France Formation range from talc schists and serpentinites 268 to chlorite schists containing primary carbonates. Within the shear zone, the schists display open to tight 269 folds with decimetric wavelengths. At least two sets of such folds are found, with axes displaying shallow 270 plunges of $5-10^{\circ}$ to the NW and SW respectively. Unfortunately, poor outcrop conditions restricted to 271 exploration trenches, among other constraints, prevented a more extensive study of fold patterns. Mineral 272 elongation lineations on shear-zone-parallel cleavages plunge preferentially to the NE, whereas shear sense indicators, such as mineral fish and asymmetric shadow zones around porphyroblasts, point to a top-to-the-south motion (Fig. 3f). These patterns in combination provide evidence for a sinistral component during a general top-to-the-south reverse faulting, similar to that observed along the Letaba Shear Zone. The latter interpretation is also in agreement with structures observed within the La France formation to the south of the shear zone. The La France schists exhibit recumbent folds axial planar to the metamorphic banding, and are affected by crenulations with shallow-plunging axes. These structures are illustrative of a shortening accommodated by reverse faulting.

To the south, the La France Formation is in contact with the $2795 \pm 8$ Ma Ma Lekkersmaak granite (Zeh et al. 2009) and with the $2820 \pm 38$ Ma Willie granite (Poujol, 2001), which form part of the Voster Suite. The granites contain micaschist xenoliths derived from the La France Formation. They are mostly undeformed except for occasional shear bands formed under sub-solidus conditions. The field relationships clearly indicate that the Lekkersmaak and Willie intrusions postdate the deformation and metamorphism in the La France Formation. 
The Antimony Line is a steeply north dipping mineralised shear zone within the Murchison Unit. The 290 dominant fabric consists of isoclinal folds axial-planar to the metamorphic banding, along with S-C 291 planes indicating a top-to-the-south motion. Mineral elongation lineations plunge vertically to moderately 292 eastwards. These structures illustrate a general transpressive, sinistral setting in the Murchison Unit, 293 accompanied by a significant reverse component (Vearncombe et al., 1988, 1992). They are consistent 294 with the kinematics observed in the Letaba and La France shear zones. At a larger scale, they are in 295 general agreement with the regional-scale sinistral transpressive regime and illustrate deformation 296 localisation in the regional strain field, described in Jaguin et al. (2012).

\section{Petrography, fabrics and mineral chemistry}

A summary of the main petrographic and textural characteristics of the rocks sampled from the different formations of the MGB is presented in Table 1. Details of analytical techniques used to determine mineral chemistry are given in Appendix (A1).

\subsection{La France Formation}

Field observations and microstructural studies of quartzites and micaschists of the La France Formation provide evidence that a primary compositional layering $\mathrm{S}_{0}$ was modified during an early $\mathrm{D}_{1}$ deformation event, leading to the formation of a composite $S_{0} / S_{1}$ foliation. The $S_{0} / S_{1}$ foliation was subsequently affected by the main $\mathrm{D}_{2}$ deformation event (Fig $4 \mathrm{~b}$, e). The latter caused the formation of the predominant $\mathrm{S}_{2}$ fabric that is axial-planar to recumbent folds. The $\mathrm{S}_{2}$ planes are mostly defined by quartz (Q) ribbons, biotite (Bt), and minor muscovite (Ms). They bear a $\mathrm{L}_{2}$ mineral elongation lineation. In metapelitic layers syn-deformation staurolite (St), garnet (Gt) and kyanite (Ky) porphyroblasts can additionally be observed, although the latter two are not found together in the same sample (Fig. 4a and 4c). Plagioclase feldspar 
315 (Pl) sillimanite (Sill) and cordierite (Crd) occasionally occur in the kyanite-bearing schists. The $\mathrm{S}_{2}$ 316 schistose planes were crenulated as a result of a $\mathrm{D}_{3}$ deformation event, leading to the formation of kinks 317 with a $\mathrm{mm}$ - to $\mathrm{cm}$-scale wavelength, and of a crude $\mathrm{S}_{3}$ cleavage. In kyanite-bearing micaschist, some 318 kyanite, staurolite and chlorite were kinked during $\mathrm{D}_{3}$ crenulation, while new chlorite, staurolite and 319 muscovite develop in the kink axes (Fig. 4f). The final minerals thus form syn- to post- $\mathrm{D}_{3}$ assemblages.

The garnet-bearing micaschists display the following peak assemblage:

$$
\text { (A): } \mathrm{Gt}+\mathrm{St}+\mathrm{Bt}_{1}+\mathrm{Ms}_{1}+\mathrm{Q}
$$

In these rocks, syn-deformation garnet porphyroblasts with quartz inclusion trails are commonly overgrown by syn-deformation staurolite, with similarly oriented quartz inclusion trails, indicating the successive formation of both minerals during the deformation event $\mathrm{D}_{2}$ (Fig. $4 \mathrm{~d}$ ). Hematite is always a retrograde phase, which formed along cracks in altered garnet grains, mostly at garnet rims. The peak metamorphic fabric is overgrown by post-deformation biotite $\left(\mathrm{Bt}_{2}\right)$ and muscovite $\left(\mathrm{Ms}_{2}\right)$. Garnet porphyroblasts show a continuous prograde growth zoning, characterised by increasing $\mathrm{X}_{\mathrm{Py}}$ $(\mathrm{Mg} /(\mathrm{Mg}+\mathrm{Fe}+\mathrm{Ca}+\mathrm{Mn}))$ from 0.05 to 0.09 and $\mathrm{Mg} \#(\mathrm{Mg} /(\mathrm{Fe}+\mathrm{Mg}))$ from 0.07 to 0.09 , and decreasing $\mathrm{X}_{\mathrm{Sps}}$ $(\mathrm{Mn} /(\mathrm{Mg}+\mathrm{Fe}+\mathrm{Ca}+\mathrm{Mn}))$ from $0.12-0.06$ to 0.03 and $\mathrm{X}_{\mathrm{Grs}}(\mathrm{Ca} /(\mathrm{Mg}+\mathrm{Fe}+\mathrm{Ca}+\mathrm{Mn}))$ from 0.07 to 0.06 , all from core to rim. Staurolite has $\mathrm{Mg} \#$ of $0.12-0.14$. The $\mathrm{Mg \#}$ of syn- $\mathrm{D}_{2}$ biotite $\left(\mathrm{Bt}_{1}\right)$ ranges from 0.32 to 0.44 range, while post- $\mathrm{D}_{2}$ biotite $\left(\mathrm{Bt}_{2}\right)$ has $\mathrm{Mg \#}=0.44$, suggesting partial reequilibration of $\mathrm{Bt}_{1}$. Muscovite $\left(\mathrm{Ms}_{1}\right.$ and $\left.\mathrm{Ms}_{2}\right)$ has low $\mathrm{Si}$ of 3.05 a.pf.u. (atoms per formular unit) and a relatively high paragonite component, as is reflected by $\mathrm{Na} /(\mathrm{Na}+\mathrm{K}+\mathrm{Ca})=0.17$. Representative mineral compositions are shown in Table 2.

Kyanite-bearing schists (B) provide evidence for the successive formation of different equilibrium assemblages during peak and retrograde evolution. The peak metamorphic conditions are illustrated by 
syn- $\mathrm{D}_{2}$ kyanite porphyroblasts that commonly contain biotite, muscovite and quartz inclusions. Some

342 rocks additionally bear syn- $\mathrm{D}_{2}$ staurolite porphyroblasts, produced with kyanite, presumably during the progressive breakdown of chlorite (which completely reacted out). Thus the thin section observations indicate that the following assemblage formed during $\mathrm{D}_{2}$ deformation at peak pressures (Fig. $4 \mathrm{~b}$ ):

(B1) $\mathrm{Ky}_{1}+\mathrm{Bt}_{1}+\mathrm{Pl}+\mathrm{Ms}_{1}+\mathrm{Q} \pm \mathrm{St}_{1}$.

The occurrence of prismatic sillimanite, as well as of fibrolite around kyanite indicates that the kyanitebearing schists crossed the phase transition Ky $\rightarrow$ Sill. The coexistence of sillimanite and cordierite (Crd) $(\mathrm{Mg \#}=0.75-0.77 ; \mathrm{Na}=0.11$ a.p.f.u. $)$, which together form patches about $0.5 \mathrm{~mm}$ wide, shows furthermore that assemblage (B1) was later (partially) replaced by the assemblage:

(B2) $\mathrm{Sill}+\mathrm{Bt}_{2}+\mathrm{Crd}+\mathrm{Pl}+\mathrm{Q}$.

(B3) $\mathrm{St}_{3}+\mathrm{Bt}_{3}+\mathrm{Ms}_{3}+\mathrm{Chl}+\mathrm{Q}$.

Retrograde staurolite $\mathrm{St}_{3}$ generally has higher $\mathrm{Mg \#}$ of 0.19-0.24 than the prograde and peak metamorphic staurolite $\mathrm{St}_{1}$, with $\mathrm{Mg \#}$ of $0.13-0.20$. In contrast, biotite from all the successive assemblages $\left(\mathrm{Bt}_{1}\right.$ to $\left.\mathrm{Bt}_{3}\right)$ overlap in compositions, with $\mathrm{Mg \#}=0.62-0.64, \mathrm{Ti}^{\mathrm{vi}}=\sim 0.06$. This is interpreted to be the result of widespread chemical reequilibration of biotite composition during metamorphic evolution. Prograde muscovite $\left(\mathrm{Ms}_{1}\right)$ always shows lower $\mathrm{Na} /(\mathrm{Na}+\mathrm{K}+\mathrm{Ca})$ of 0.08 and higher silica contents $(\mathrm{Si}=3.15$ a.p.f.u.) than retrograde muscovite $\left(\mathrm{Ms}_{3}\right)$, with $\mathrm{Na} /(\mathrm{Na}+\mathrm{K}+\mathrm{Ca})=0.18$ and $\mathrm{Si}=3.02$ a.p.f.u.. M. 
$/(\mathrm{Na}+\mathrm{K}+\mathrm{Ca})=0.08$. Retrograde chlorite of assemblage $(\mathrm{B} 3)$ has $\mathrm{Mg} \#=0.66-0.69$, and high- $\mathrm{Al}$ contents 368 of 1.35 a.p.f.u. Plagioclase grains show a wide range of chemical compositions, with $\mathrm{X}_{\mathrm{An}}(\mathrm{Ca} / \mathrm{Ca}+\mathrm{Na})=$ 0.09 to 0.41 , and a majority of grains having $\mathrm{X}_{\mathrm{An}} \sim 0.4$.

In one sample from the same formation, centimetric euhedral kyanite $\left(\mathrm{Ky}_{3}\right)$ and staurolite $\left(\mathrm{St}_{3}\right)$ crystals overgrow the $S_{2}$ metamorphic banding, together with millimetric biotite and muscovite grains (Fig. 4e and 4f). This assemblage, equivalent to $\left(\mathrm{B}_{3}\right)$ in more aluminous lithologies, suggests that the Sill $\rightarrow \mathrm{Ky}$ phase transition was crossed during the retrograde evolution of the rock. Furthermore, the retrograde assemblages $\left(\mathrm{B}_{2}\right)$ and $\left(\mathrm{B}_{3}\right)$ are characterised by the formation of abundant hydrated minerals, indicating a secondary, $\mathrm{H}_{2} \mathrm{O}$-rich fluid enrichment after peak metamorphism.
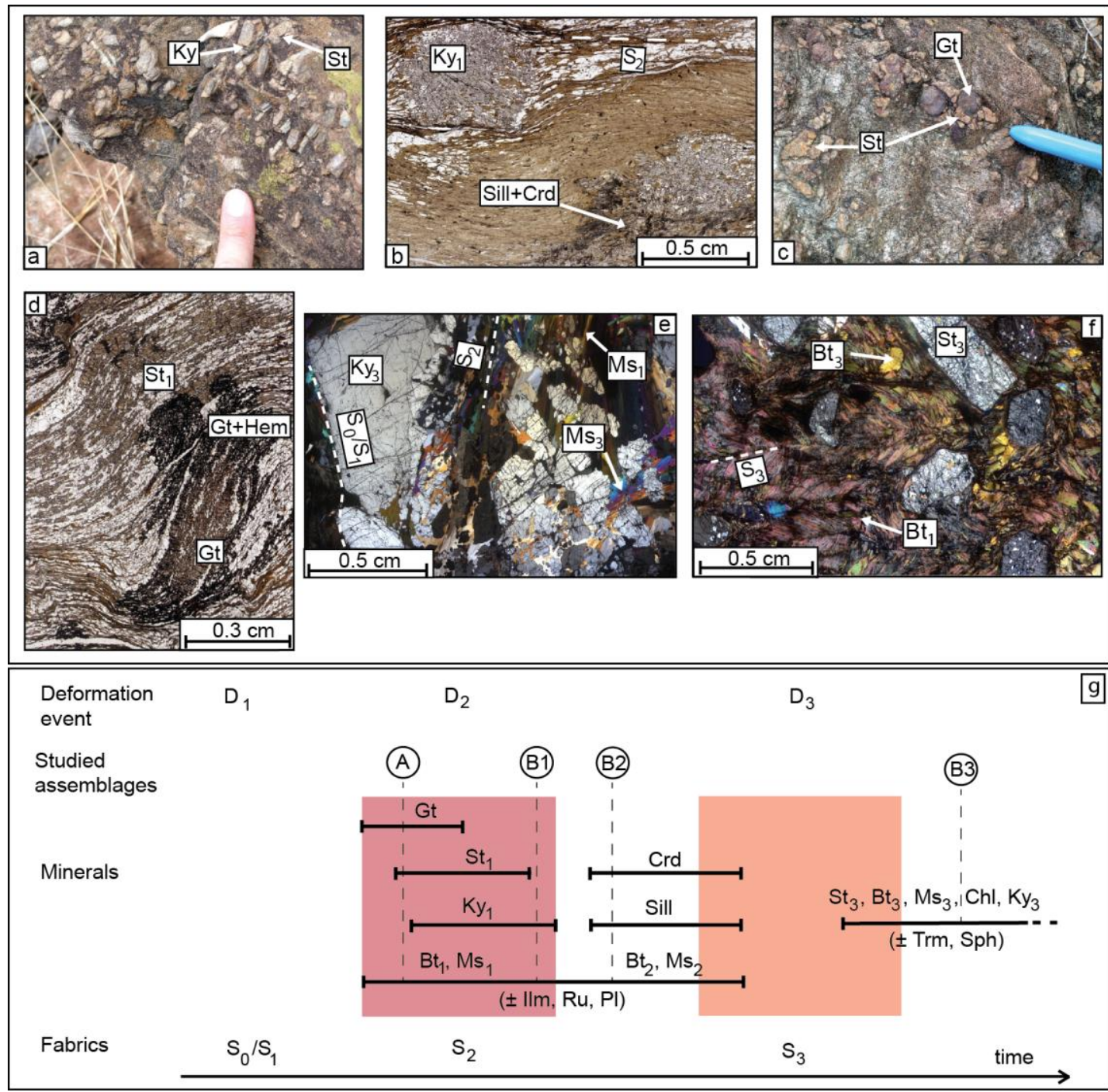

Figure 4:

Petrographic features observed in rocks of the La France formation. (a) Biotite micaschist with protruding staurolite (St) and kyanite (Ky) porphyroblasts. (b) Thin section of a kyanite- staurolite- 
cordierite-bearing micaschist (sample B). Ky porphyroblasts are surrounded by foliation-parallel biotite and quartz (top), or are overgrown by patches of sillimanite and cordierite. (c) Garnet (Gt)- staurolitebearing micaschist (sample A). (d) Thin section of sample A showing highly deformed and rotated St and Gt porphyroblasts (syn- $D_{2}$ ), set in a matrix of biotite, muscovite and quartz. Hematite (Hem) occurs along cracks mostly in garnet rims, probably resulting from retrograde alteration. Biotite and muscovite define the syn- $D_{2}$ metamorphic banding. (e) and ( $f$ ) Thin sections of a Ky-St-bearing schist from the La France formation showing, (e) a compositional layering $S_{0} / S_{1}$ delimiting a kyanite and muscovite-rich layer, with Ky overgrowing the $D_{2}$ metamorphic fabric, $(f)$ a crenulated domain, with euhedral staurolite and a crude $\mathrm{S}_{3}$ cleavage. ( $g$ ) Synopsis showing the relative temporal relationships between deformation and assemblage formation in the La France Formation (Ilm: Ilmenite, Ru : Rutile, Trm : Tourmaline, Sph : Sphene).

\subsection{Silwana Amphibolites}

The Silwana Amphibolites trend ENE - WSW and show a vertical to steeply north-dipping $\mathrm{S}_{0} / \mathrm{S}_{1}$ layering defined by modal variations of quartz, plagioclase and hornblende ( $\mathrm{Hbl})$ across bands about $10 \mathrm{~cm}$ thick. On a smaller scale, the amphibolites develop a planar $(S>L)$, flattening tectonic fabric $S_{2}$. The metamorphic banding $S_{2}$, is subparallel to the $S_{0} / S_{1}$ layering. It is defined by the alternation of millimetric hornblende-rich and quartz- plagioclase-rich bands. The latter display an equigranular texture, suggesting a relatively high temperature recrystallisation $\left(>500^{\circ} \mathrm{C}\right)$. The $\mathrm{S}_{2}$ foliation bears a dominant steep easterly dipping mineral lineation $\mathrm{L}_{2}$ defined by hornblende. At the north-western extremity of the sliver, the strike of the layering changes dramatically from ENE-WSW to NW-SE, with a steep north-easterly dip, while the $S_{2}$ foliation carries a steep, north-plunging mineral elongation lineation. It is likely that both the ENE- and NW-trending structures (and related lineations) result from activation of a conjugate shear system. Garnet occurs as an additional phase in rare Al- and Fe-rich layers. Biotite is also present in small proportions $(\sim 1-2$ modal $\%)$. Epidote $(\mathrm{Ep})$ is a retrograde phase and frequently formed in cross-cutting veins, in association with carbonates. Chlorite is found in cracks within garnet porphyroblasts The peak metamorphic assemblage is interpreted to be: 
(S) $\mathrm{Gt}+\mathrm{Hbl}+\mathrm{Pl}+\mathrm{Bt}+\mathrm{Ilm}+\mathrm{Q}$.

411 The garnet prophyroblasts show a slight prograde growth zoning, as is reflected by increasing $\mathrm{X}_{\mathrm{Py}}$ (from 4120.055 to $0.060, \mathrm{Mg \#}$ varies from 0.67 to 0.73 ) and $\mathrm{X}_{\mathrm{Grs}}$ (from 0.13 to 0.15 ), and decreasing $\mathrm{X}_{\mathrm{Sps}}$ (from 4130.04 to 0.03$)$ and $\mathrm{X}_{\mathrm{Alm}}(\mathrm{Fe} /(\mathrm{Fe}+\mathrm{Mg}+\mathrm{Ca}+\mathrm{Mn})$ from 0.77 to 0.76$)$ from core to rim. Garnet contains 414 inclusions of hornblende, quartz and ilmenite. Hornblende inclusions in garnet show some scatter in their 415 chemical composition, with $\mathrm{Mg \#}=0.21-0.26$ and $\mathrm{Ca} / \mathrm{Na}=3.0-3.6$, compared to $\mathrm{Mg \#}=0.23-0.26$ and $416 \mathrm{Ca} / \mathrm{Na}=2.8-3.0$ for matrix hornblende. Matrix plagioclase has a constant chemical composition, with $\mathrm{X}_{\mathrm{An}}$ $417=0.17$. Biotite occurrence is limited, with small grains elongated parallel to hornblende, and some 418 randomly oriented grains occurring around garnet. All matrix biotites show similar compositions with $\mathrm{Mg} \#=0.22-0.26$ and $\mathrm{Ti}^{\mathrm{vi}}=0.1$ a.p.f.u.. Retrograde chlorite $(\mathrm{Mg} \#=\sim 0.36)$ only formed along cracks in the garnet porphyroblasts.

\subsection{Murchison Unit}

Strain distribution in the Murchison Unit is fairly heterogeneous. Minor domains, far from tectonic discontinuities, are almost undeformed, but most rocks displays a pervasive schistose fabric and provide evidence for a poly-phased deformation (Vearncombe, 1988 ; Vearncombe et al., 1988, 1992 ; Jaguin et al., 2012). Primary sedimentary structures $S_{0}$, are only preserved in competent layers. Stratigraphic contacts between the different formations of the Murchison Unit have been completely reworked by tectonic processes during the successive deformation events. A first deformation episode $\mathrm{D}_{1}$ corresponds to the formation isoclinal folds axial-planar to a $S_{1}$ cleavage trending ENE. These isoclinal folds are transposed by E-W trending, S-shaped asymmetric folds, axial planar to a $\mathrm{S}_{2}$ cleavage, formed during a second deformation event, $\mathrm{D}_{2}$. However, it is generally difficult to attribute the pervasive cleavages to either $D_{1}$ or $D_{2}$. None of our samples exhibit the $D_{3}$ crenulation cleavage, which was recognised by 
435 Vearncombe et al. $(1988,1992)$ in rocks near to the Antimony Line. For P-T path estimates, we 436 investigated a sample from a nearly undeformed metamafic rock from the centre of the Murchison Unit, 437 south of the Antimony Line (sample M1); and a sample from a deformed quartzite with metapelitic layers 438 from the southern edge of the Murchison Unit (sample M2), a few dozen metres north from the contact 439 with the Makhutswi gneisses (Fig. 2). The metabasite sample M1 contains the following peak 440 metamorphic mineral assemblage:

441

442

443

(M1) Act (actinolite) $+\mathrm{Ab}($ albite $)+\mathrm{Ep}+\mathrm{Chl}+\mathrm{Sph}($ sphene $)$

with Chl mostly in late shear bands. The actinolite needles display a garbenscheifer texture, which might represent pseudomorphs of primary magmatic textures, and have $\mathrm{Mg} \#=0.67-0.72$. The feldspar is pure albite $\left(\mathrm{X}_{\mathrm{An}} \leq 0.01\right)$. Chlorite has $\mathrm{Mg \#}=0.55-0.56$ and $\mathrm{Al}^{\mathrm{vi}}=1.20$ a.p.f.u..

The metapelitic-quartzitic sample M2 displays the following peak mineral assemblage:

$(\mathrm{M} 2) \mathrm{Gt}+\mathrm{Ms}+\mathrm{Bt}+\mathrm{Chl}+\mathrm{Qtz}$

and additionally contains retrograde chlorite along garnet cracks. Garnet porphyroblasts have diameters < $0.5 \mathrm{~mm}$ and do not display any chemical zoning. The garnets have a high almandine components of $\mathrm{X}_{\mathrm{Alm}}$ $=0.8$, low pyrope and spessartine components $\left(\mathrm{X}_{\mathrm{Py}}=\mathrm{X}_{\mathrm{Sps}}=\sim 0.1\right)$, and $\mathrm{Mg} \#=0.08-0.10$. Biotite is Tipoor $\left(\mathrm{Ti}^{\mathrm{vi}}=0.07\right.$ a.p.f.u. $)$ and has a $\mathrm{Mg} \#=0.39-0.44$. Chlorite has $\mathrm{Mg} \#=0.36-0.39$ and $\mathrm{Al}^{\mathrm{vi}}=1.55-1.70$ a.p.f.u. Muscovite is $\mathrm{Na}$-poor, with $\mathrm{Na} /(\mathrm{Na}+\mathrm{K}+\mathrm{Ca})=0.13$, and $\mathrm{Si}=3.1$ a.p.f.u..

\section{Table 2:}

Major element compositions and structural formulae of representative mineral analyses of the peak and retrograde assemblages in lithologies from the La France Formation, Murchison Unit and Silwana Amphibolites. 


\begin{tabular}{|c|c|c|c|c|c|c|c|c|c|c|}
\hline \multirow{2}{*}{$\begin{array}{l}\text { Sample } \\
\text { Mineral } \\
\text { phase }\end{array}$} & \multicolumn{10}{|c|}{ A (garnet- staurolite micaschist of the La France Formation) } \\
\hline & $\begin{array}{l}\text { Gt } \\
\text { (core) }\end{array}$ & Gt (core) & Gt(rim) & St (core) & St (rim) & $\mathrm{Bt}_{1}$ & $\mathrm{Bt}_{1}$ & $\mathrm{Bt}_{2}$ & $\mathrm{Ms}_{1}$ & $\mathrm{Ms}_{2}$ \\
\hline \multicolumn{11}{|l|}{$w t \%$} \\
\hline $\mathrm{Na}_{2} \mathrm{O}$ & & & & b.d.l. & b.d.l. & 0.08 & 0.16 & 0.22 & 1.23 & 1.31 \\
\hline $\mathrm{MgO}$ & 1.36 & 1.67 & 2.21 & 1.36 & 1.22 & 7.39 & 5.10 & 8.19 & 0.42 & 0.45 \\
\hline $\mathrm{Al}_{2} \mathrm{O}_{3}$ & 20.7 & 20.7 & 21.0 & 53.9 & 54.2 & 21.6 & 21.3 & 19.8 & 36.6 & 36.5 \\
\hline $\mathrm{SiO}_{2}$ & 36.5 & 36.7 & 36.6 & 26.4 & 26.3 & 37.9 & 36.4 & 34.8 & 46.0 & 45.9 \\
\hline $\mathrm{K}_{2} \mathrm{O}$ & & & & & & 7.22 & 7.50 & 6.61 & 9.22 & 9.46 \\
\hline $\mathrm{CaO}$ & 2.65 & 2.07 & 1.95 & b.d.l. & b.d.I. & 0.14 & 0.16 & 0.08 & 0.01 & 0.04 \\
\hline $\mathrm{TiO}_{2}$ & & & & 0.22 & 0.34 & 0.98 & 0.65 & 0.95 & 0.09 & 0.07 \\
\hline $\mathrm{Cr}_{2} \mathrm{O}_{3}$ & & & & & & 0.03 & 0.05 & 0.03 & 0.07 & 0.01 \\
\hline $\mathrm{MnO}$ & 5.44 & 3.59 & 1.17 & 0.02 & 0.06 & 0.01 & b.d.l. & b.d.I. & b.d.I. & 0.01 \\
\hline $\mathrm{FeO}$ & 34.2 & 35.0 & 37.6 & 15.7 & 15.1 & 16.8 & 19.4 & 18.4 & 1.16 & 1.04 \\
\hline Total & 100.8 & 100.4 & 100.4 & 97.6 & 97.2 & 92.1 & 90.7 & 89.1 & 94.8 & 94.7 \\
\hline Oxygens & 12 & 12 & 12 & 48 & 48 & 22 & 22 & 22 & 22 & 22 \\
\hline $\mathrm{Si}$ & 5.93 & 5.97 & 5.93 & 7.42 & 7.41 & 5.76 & 5.73 & 5.54 & 6.11 & 6.11 \\
\hline $\mathrm{Al}^{\mathrm{IV}}$ & 0.07 & 0.03 & 0.07 & 0.58 & 0.59 & 2.24 & 2.27 & 2.46 & 1.89 & 1.89 \\
\hline $\mathrm{Al}^{\mathrm{VI}}$ & 3.94 & 3.98 & 3.90 & 17.3 & 17.4 & 1.70 & 1.59 & 1.26 & 3.84 & 3.83 \\
\hline$\simeq \mathrm{Fe}^{3+}$ & 0.19 & 0.03 & 0.25 & 0.67 & 0.55 & & & & & \\
\hline$\stackrel{\sim}{\mathrm{N}} \mathrm{Ti}$ & & & & 0.05 & 0.07 & 0.10 & 0.11 & 0.11 & 0.01 & 0.01 \\
\hline $\bar{\alpha} \mathrm{Cr}$ & & & & & & 0.00 & 0.00 & 0.00 & & \\
\hline$\frac{\pi}{<} M g$ & 0.53 & 0.39 & 0.33 & 0.57 & 0.51 & 1.58 & 1.67 & 1.94 & 0.08 & 0.09 \\
\hline$\stackrel{\bullet}{\sim} \mathrm{Fe}^{2+}$ & 4.90 & 4.87 & 4.39 & 3.03 & 3.00 & 2.10 & 2.12 & 2.45 & 0.13 & 0.12 \\
\hline$\frac{1}{-} \mathrm{Mn}^{2+}$ & 0.16 & 0.37 & 0.75 & 0.01 & 0.01 & 0.00 & & & & \\
\hline$\subsetneq \mathrm{Ca}$ & 0.34 & 0.39 & 0.46 & & & 0.07 & 0.02 & 0.01 & 0.00 & 0.01 \\
\hline 응 $\mathrm{Na}$ & & & & & & 0.01 & 0.02 & 0.07 & 0.32 & 0.34 \\
\hline (1) $\mathrm{K}$ & & & & & & 1.23 & 1.39 & 1.34 & 1.56 & 1.61 \\
\hline$>x[\mathrm{Py}]$ & 0.05 & 0.06 & 0.09 & & & & & & & \\
\hline$\stackrel{\llcorner}{N} \times[$ Alm $]$ & 0.75 & 0.81 & 0.83 & & & & & & & \\
\hline$\stackrel{1}{2} \times[\mathrm{Sps}]$ & 0.12 & 0.06 & 0.03 & & & & & & & \\
\hline $8 \times[G r s]$ & 0.07 & 0.06 & 0.06 & & & & & & & \\
\hline gFe[fcel] & & & & & & & & & 0.06 & 0.06 \\
\hline \#/g[mcel] & & & & & & & & & 0.04 & 0.04 \\
\hline Al|[mphen] & & & & & & & & & 0.89 & 0.90 \\
\hline
\end{tabular}

Sample $\quad$ B (kyanite- plagioclase micaschist of the La France Formation)

\begin{tabular}{|c|c|c|c|c|c|c|c|c|c|c|c|c|}
\hline $\begin{array}{c}\text { Mineral } \\
\text { phase }\end{array}$ & $\mathrm{PI}$ & $\mathrm{PI}$ & $\mathrm{St}_{3}$ & $\mathrm{St}_{3}$ & $\mathrm{Bt}_{1}$ & $\mathrm{Bt}_{3}$ & Crd & Crd & $\mathrm{Wm}_{1}$ & $\mathrm{Wm}_{3}$ & Chl & Chl \\
\hline \multicolumn{13}{|l|}{$w t \%$} \\
\hline $\mathrm{Na}_{2} \mathrm{O}$ & 6.65 & 10.5 & & & 0.35 & 0.21 & 0.68 & 0.44 & 0.36 & 1.41 & b.d.I. & 0.03 \\
\hline $\mathrm{MgO}$ & 0.01 & 0.02 & 1.98 & 2.17 & 13.26 & 14.40 & 9.56 & 9.68 & 2.76 & 1.19 & 18.8 & 19.4 \\
\hline $\mathrm{Al}_{2} \mathrm{O}_{3}$ & 26.9 & 21.2 & 54.1 & 53.9 & 19.4 & 19.2 & 32.6 & 32.8 & 33.1 & 36.8 & 22.9 & 22.7 \\
\hline $\mathrm{SiO}_{2}$ & 57.3 & 66.1 & 28.9 & 29.1 & 36.5 & 35.2 & 49.1 & 49.0 & 46.6 & 46.0 & 25.5 & 26.0 \\
\hline $\mathrm{K}_{2} \mathrm{O}$ & 0.04 & b.d.l. & & & 9.12 & 8.40 & 0.01 & 0.02 & 6.02 & 9.28 & 0.44 & 0.68 \\
\hline $\mathrm{CaO}$ & 8.45 & 1.99 & b.d.I. & b.d.I. & 0.04 & 0.04 & 0.07 & 0.03 & 0.42 & 0.02 & 0.10 & 0.05 \\
\hline $\mathrm{TiO}_{2}$ & 0.01 & b.d.l. & 0.13 & 0.05 & 1.09 & 0.69 & 0.06 & b.d.I. & 0.00 & 0.04 & 0.02 & 0.05 \\
\hline $\mathrm{Cr}_{2} \mathrm{O}_{3}$ & & & 0.06 & b.d.I. & 0.24 & 0.14 & & & & & 0.05 & 0.37 \\
\hline $\mathrm{MnO}$ & 0.01 & 0.02 & 0.48 & 0.42 & 0.08 & 0.13 & 0.19 & 0.12 & 0.01 & 0.02 & 0.16 & 0.11 \\
\hline $\mathrm{FeO}$ & & & 12.3 & 12.2 & 13.9 & $21^{15.3}$ & 5.57 & 5.41 & 2.79 & 1.06 & 17.3 & 16.4 \\
\hline
\end{tabular}




\begin{tabular}{|c|c|c|c|c|c|c|c|c|c|c|c|c|}
\hline $\mathrm{Fe}_{2} \mathrm{O}_{3}$ & b.d.I. & 0.06 & & & & & & & & & & \\
\hline Total & 99.4 & 99.8 & 98.0 & 97.8 & 94.0 & 93.7 & 97.9 & 97.4 & 92.0 & 95.9 & 85.2 & 85.8 \\
\hline Oxygens & 32 & 32 & 48 & 48 & 22 & 22 & 18 & 18 & 22 & 22 & 28 & 28 \\
\hline $\mathrm{Si}$ & 10.3 & 11.6 & 7.95 & 8.00 & 5.47 & 5.32 & 5.03 & 5.03 & 6.29 & 6.06 & 5.30 & 5.35 \\
\hline $\mathrm{Al}^{\mathrm{IV}}$ & 5.72 & 4.39 & 0.05 & & 2.53 & 2.68 & 0.97 & 0.97 & 1.71 & 1.94 & 2.70 & 2.65 \\
\hline $\mathrm{Al}^{\mathrm{VI}}$ & & & 17.5 & 17.5 & 0.89 & 0.74 & 2.97 & 2.99 & 3.57 & 3.77 & 2.92 & 2.86 \\
\hline $\mathrm{Fe}^{3+}$ & & & 0.49 & 0.53 & & & & & & & & \\
\hline $\mathrm{Ti}$ & & & 0.03 & 0.01 & 0.12 & 0.08 & & & & & & 0.01 \\
\hline $\mathrm{Cr}$ & & & 0.01 & & 0.03 & 0.02 & & & & & 0.01 & 0.06 \\
\hline $\mathrm{Mg}$ & & & 0.81 & 0.89 & 2.96 & 3.24 & 1.46 & 1.48 & 0.56 & 0.23 & 5.84 & 5.97 \\
\hline $\mathrm{Fe}^{2+}$ & & 0.01 & 2.34 & 2.27 & 1.74 & 1.94 & 0.48 & 0.46 & 0.32 & 0.12 & 3.01 & 2.82 \\
\hline $\mathrm{Mn}^{2+}$ & & & 0.11 & 0.10 & 0.01 & 0.02 & 0.02 & 0.01 & & & 0.03 & 0.02 \\
\hline $\mathrm{Ca}$ & 1.63 & 0.38 & & & 0.01 & 0.01 & 0.01 & & 0.06 & & 0.02 & 0.01 \\
\hline $\mathrm{Na}$ & 2.32 & 3.57 & & & 0.10 & 0.06 & 0.14 & 0.09 & 0.10 & 0.36 & & 0.01 \\
\hline $\mathrm{K}$ & 0.01 & & & & 1.74 & 1.62 & & & 1.04 & 1.56 & 0.12 & 0.18 \\
\hline $\mathrm{xK}$ [Or] & 0.00 & 0.01 & & & & & & & & & & \\
\hline $\mathrm{xNa}[\mathrm{Ab}]$ & 0.59 & 0.90 & & & & & & & & & & \\
\hline xCa [An] & 0.41 & 0.09 & & & & & & & & & & \\
\hline$x F e[f c e l]$ & & & & & & & & & 0.14 & 0.06 & & \\
\hline xMg[mcel] & & & & & & & & & 0.25 & 0.11 & & \\
\hline All[mphen] & & & & & & & & & 0.61 & 0.83 & & \\
\hline
\end{tabular}

\begin{tabular}{|c|c|c|c|c|c|c|c|c|}
\hline Sample & M1 (gree & from & rchisor & & & & & \\
\hline Mineral phase & Act & Act & $\mathrm{Chl}$ & Chl & $\mathrm{Pl}$ & $\mathrm{PI}$ & Ep & Sph \\
\hline \multicolumn{9}{|l|}{$w t \%$} \\
\hline $\mathrm{Na}_{2} \mathrm{O}$ & & & & & 11.7 & 11.9 & & \\
\hline $\mathrm{MgO}$ & 19.6 & 19.0 & 21.5 & 22.7 & & & & \\
\hline $\mathrm{Al}_{2} \mathrm{O}_{3}$ & 1.02 & 0.96 & 20.1 & 20.5 & 19.6 & 19.9 & 21.9 & 0.69 \\
\hline $\mathrm{SiO}_{2}$ & 56.2 & 55.3 & 27.5 & 27.9 & 67.5 & 67.4 & 36.8 & 30.6 \\
\hline $\mathrm{K}_{2} \mathrm{O}$ & & & & & b.d.I. & b.d.I. & & \\
\hline $\mathrm{CaO}$ & 13.0 & 13.1 & & & 0.12 & 0.20 & 23.13 & 29.0 \\
\hline $\mathrm{TiO}_{2}$ & b.d.l. & 0.16 & b.d.l. & 0.16 & & & & 37.9 \\
\hline $\mathrm{Cr}_{2} \mathrm{O}_{3}$ & 0.52 & 0.18 & 0.34 & 0.21 & & & & 0.26 \\
\hline $\mathrm{MnO}$ & 0.26 & 0.23 & 0.23 & 0.19 & & & & \\
\hline $\mathrm{FeO}$ & 8.53 & 9.70 & 17.58 & 17.92 & & & & 0.41 \\
\hline $\mathrm{Fe}_{2} \mathrm{O}_{3}$ & & & & & b.d.l. & 0.30 & 15.0 & \\
\hline Total & 99.1 & 98.6 & 87.2 & 89.6 & 98.8 & 99.7 & 96.8 & 98.8 \\
\hline Oxygens & 23 & 23 & 28 & 28 & 32 & 32 & 13 & 5 \\
\hline Si & 7.82 & 7.79 & 5.59 & 5.52 & 11.9 & 11.9 & 3.10 & 1.01 \\
\hline $\mathrm{Al}^{\mathrm{IV}}$ & 0.17 & 0.16 & 2.41 & 2.48 & 4.08 & 4.12 & & 0.03 \\
\hline $\mathrm{Al}^{\mathrm{VI}}$ & & & 2.39 & 2.30 & & & 2.17 & \\
\hline $\mathrm{Fe}^{3+}$ & & & & & & 0.03 & 0.95 & 0.01 \\
\hline $\mathrm{Ti}$ & & 0.02 & & 0.02 & & & & 0.94 \\
\hline $\mathrm{Cr}$ & 0.06 & 0.02 & 0.05 & 0.03 & & & & 0.01 \\
\hline $\mathrm{Mg}$ & 4.06 & 3.98 & 6.51 & 6.69 & & & & \\
\hline $\mathrm{Fe}^{2+}$ & 0.99 & 1.14 & 2.99 & 2.97 & & 0.01 & 0.01 & \\
\hline $\mathrm{Mn}^{2+}$ & 0.03 & 0.03 & 0.04 & 0.03 & & & & \\
\hline $\mathrm{Ca}$ & 1.94 & 1.97 & & & 0.02 & 0.04 & & 1.02 \\
\hline $\mathrm{Na}$ & & & & & 4.00 & 4.04 & & \\
\hline $\mathrm{K}$ & & & & & & & & \\
\hline $\mathrm{xK}$ [Or] & & & & & & & & \\
\hline $\mathrm{xNa}[\mathrm{Ab}]$ & & & & & 0.99 & 0.99 & & \\
\hline$x \mathrm{Ca}[\mathrm{An}]$ & & & & & 0.01 & 0.01 & & \\
\hline$x[c Z o]=x[Z o]$ & & & & & & & 0.09 & \\
\hline
\end{tabular}



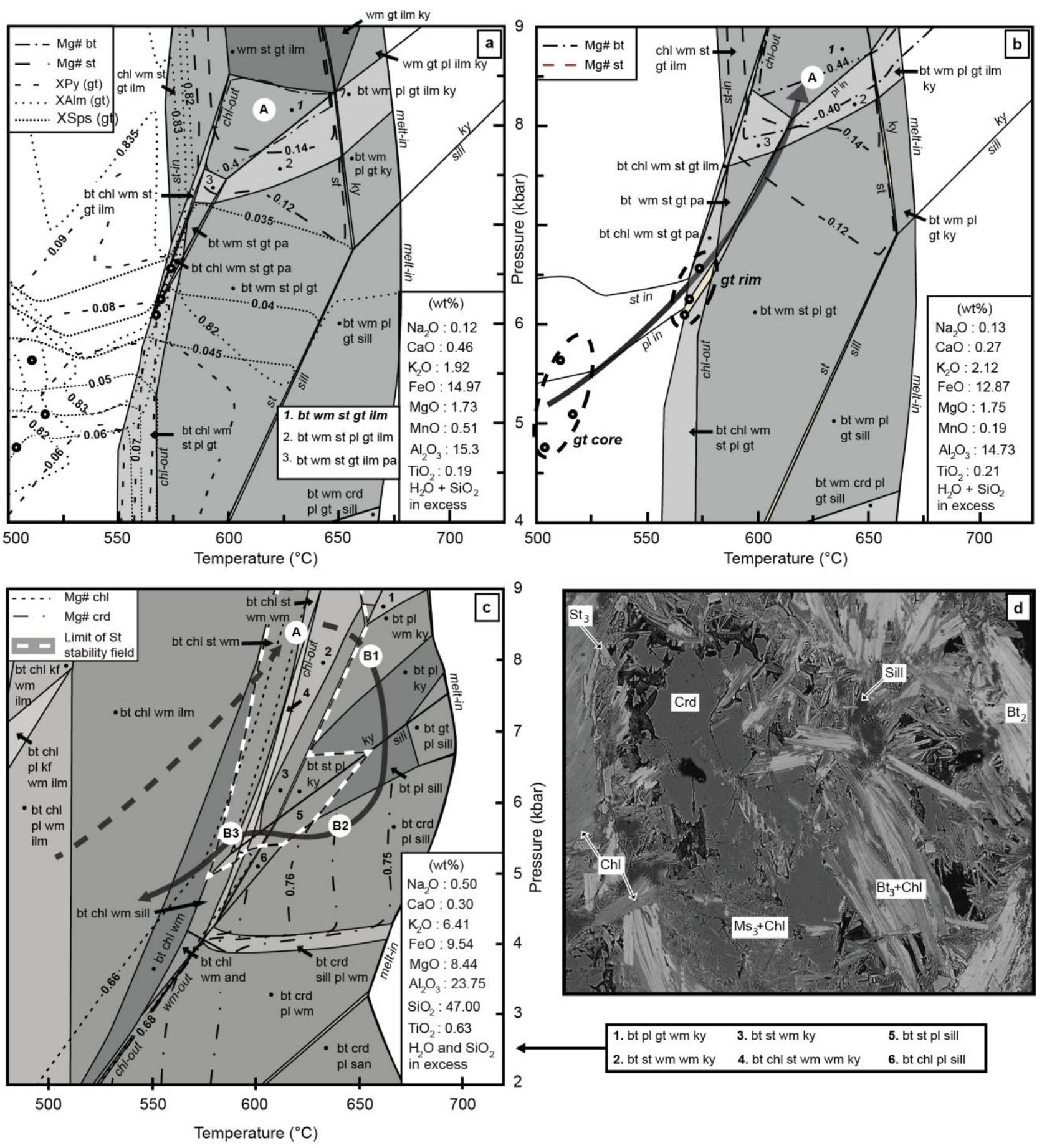

Figure 5:

$P$ - T pseudosections for metapelitic rocks from the La France Formation, constructed in the model system (Mn)TiNCKFMASH (with $\mathrm{H}_{2} \mathrm{O}$ and $\mathrm{SiO}_{2}$ in excess). $(a, b) P-T$ pseudosection for a garnetstaurolite micaschist (sample A) and (c) for a kyanite-bearing micaschist with retrograde cordierite and staurolite (sample B). The P-T pseudosection (a) is constructed by using the unfractionated bulk composition obtained by XRF analysis, and (b) is built by using the effective bulk composition after garnet growth ceased. Small open circles represent fit between calculated and measured garnet compositions, obtained from garnet cores and rims of zoned garnet in sample A. White circles labelled A, 
and mineral compositions. The arrows define the $P-T$ path inferred from the petrological constraints. (d) SEM image of sample B showing tiny staurolite grains $\left(S t_{3}\right)$, which together with chlorite (Chl), biotite $\left(\mathrm{Bt}_{3}\right)$ and muscovite $\left(\mathrm{Ms}_{3}\right)$ surround a cordierite (Crd) porphyroblast, intergrown with sillimanite (Sill) and biotite $\left(B t_{2}\right) . W m=$ white mica .

\subsection{La France Formation}

$\mathrm{P}-\mathrm{T}$ pseudosections for the La France Formation were calculated for a Gt-St-bearing schist (sample A) and a Ky-St-Crd schist (sample B), which were collected about 300m apart. In the absence of any tectonic break between the two outcrops we assume that both rocks underwent the same metamorphic history, and consequently, that the different mineral assemblages and compositions result from different bulk rock compositions. Thus a detailed $\mathrm{P}-\mathrm{T}$ path can be constructed by superimposing the information obtained from the different rock samples (e.g. Zeh et al., 2001, 2004; Reno et al. 2009).

Results of $\mathrm{P}-\mathrm{T}$ pseudosections for sample A (Fig 5a, b) indicate that the Gt-St-bearing schists of the La France Formation experienced a prograde $\mathrm{P}-\mathrm{T}$ increase from about $5.5 \mathrm{kbar}, 520{ }^{\circ} \mathrm{C}$ to $7.5-9.0 \mathrm{kbar}$, 590-650 ${ }^{\circ} \mathrm{C}$. The prograde $\mathrm{P}-\mathrm{T}$ evolution is constrained by the agreement between observed and calculated garnet zoning patterns, using the "garnet isopleths intercept method" (e.g., Evans 2004; Zeh et al., 2006). The peak $\mathrm{P}-\mathrm{T}$ conditions are determined from the correspondence between the calculated and observed peak mineral assemblage (A): $\mathrm{Grt}+\mathrm{St}+\mathrm{Bt}_{1}+\mathrm{Ms}_{1}+\mathrm{Q}$, and related mineral compositions. It should be noted, however, that the fit between calculated and observed peak mineral compositions is not perfect, i.e. the calculated mineral compositions of garnet rims plot outside the phase field for the peak mineral assemblage (Fig. 5). This discrepancy may be explained by at least two reasons. Firstly, minerals in sample A underwent a retrograde equilibration (causing a change of the peak mineral composition of garnet rims and of biotites; e.g. Florence \& Spear, 1991), and/or secondly, by internal fractionation, causing a change of the effective bulk composition during prograde garnet growth (e.g. Stüwe, 1997; Marmo et al., 2002; Zeh et al., 2006). The effects of chemical fractionation due to garnet growth are 
modelled in Fig 5. Assemblage (A) is shifted from 7.5-8.5 kbar, 590-645 ${ }^{\circ} \mathrm{C}$ for the unfractionated rock (Fig. 5a) to higher $\mathrm{P}-\mathrm{T}$ conditions of $8.0-9.0 \mathrm{kbar}, 600-650^{\circ} \mathrm{C}$ when fractionation is taken into account (Fig. 5b).

The peak metamorphic assemblage $(\mathrm{B} 1) \mathrm{Ky}_{1}+\mathrm{Bt}_{1}+\mathrm{Pl}+\mathrm{Ms}_{1}+\mathrm{Q} \pm \mathrm{St}_{1}$ observed in sample $\mathrm{B}$ requires peak $\mathrm{P}-\mathrm{T}$ conditions of $6.8-9.0 \mathrm{kbar}$ at $630-650^{\circ} \mathrm{C}$. Comparison of the peak metamorphic conditions for sample $\mathrm{B}$ and the prograde $\mathrm{P}-\mathrm{T}$ vector inferred for sample $\mathrm{A}$ indicates that the formation underwent a limited heating after reaching peak pressure. Syn-D2 muscovite in sample B has a modal proportion < $1 \%$, suggesting equilibration near the white mica-out reaction curve that limits the multivarient field at lower pressures. Sillimanite overgrowth around kyanite and the finding of cordierite in assemblage (B2): Sill $+\mathrm{Bt}_{2}+\mathrm{Crd}+\mathrm{Pl}+\mathrm{Q}$, provide evidence for a nearly isothermal decompression to $\mathrm{P}-\mathrm{T}$ conditions of $<6 \mathrm{kbar}$ at $600-660^{\circ} \mathrm{C}$ during retrograde evolution (Fig. 5c.). Cordierite is partly replaced by an assemblage including St, Sill, Bt, Ms and Chl (assemblage (B3): $\mathrm{St}_{3}+\mathrm{Bt}_{3}+\mathrm{Chl}+\mathrm{Ms}_{3}+\mathrm{Q}$, Fig. 5d.), implying that the near isothermal decompression was followed by a near-isobaric cooling to $<600^{\circ} \mathrm{C}$ at 5.5 kbar. The change in the $\mathrm{P}-\mathrm{T}$ path from a near-isothermal decompression to a near-isobaric cooling may correspond to the onset of the $\mathrm{D}_{3}$ deformation event.

\subsection{Silwana Amphibolites}

Results of $\mathrm{P}-\mathrm{T}$ pseudosection calculations indicate that the observed peak metamorphic assemblage (S): $\mathrm{Gt}+\mathrm{Hbl}+\mathrm{Pl}+\mathrm{Bt}+\mathrm{Ilm}+\mathrm{Q}$ is stable over a wide $\mathrm{P}-\mathrm{T}$ range at temperatures between 540 and $690^{\circ} \mathrm{C}$ and pressures between 4.6 and $>11$ kbar (Fig. 6). A prograde $\mathrm{P}-\mathrm{T}$ path is inferred by comparing the observed and calculated mineral composition of garnet (cores and rims), amphibole inclusions in garnet and matrix amphibole, as well as of matrix plagioclase. Intersecting the isopleths for these minerals provides evidence for a $\mathrm{P}-\mathrm{T}$ increase from $\sim 4.5 \mathrm{kbar}, 540{ }^{\circ} \mathrm{C}$, to peak metamorphic conditions of 8.7-10 kbar at $630-670^{\circ} \mathrm{C}$. 


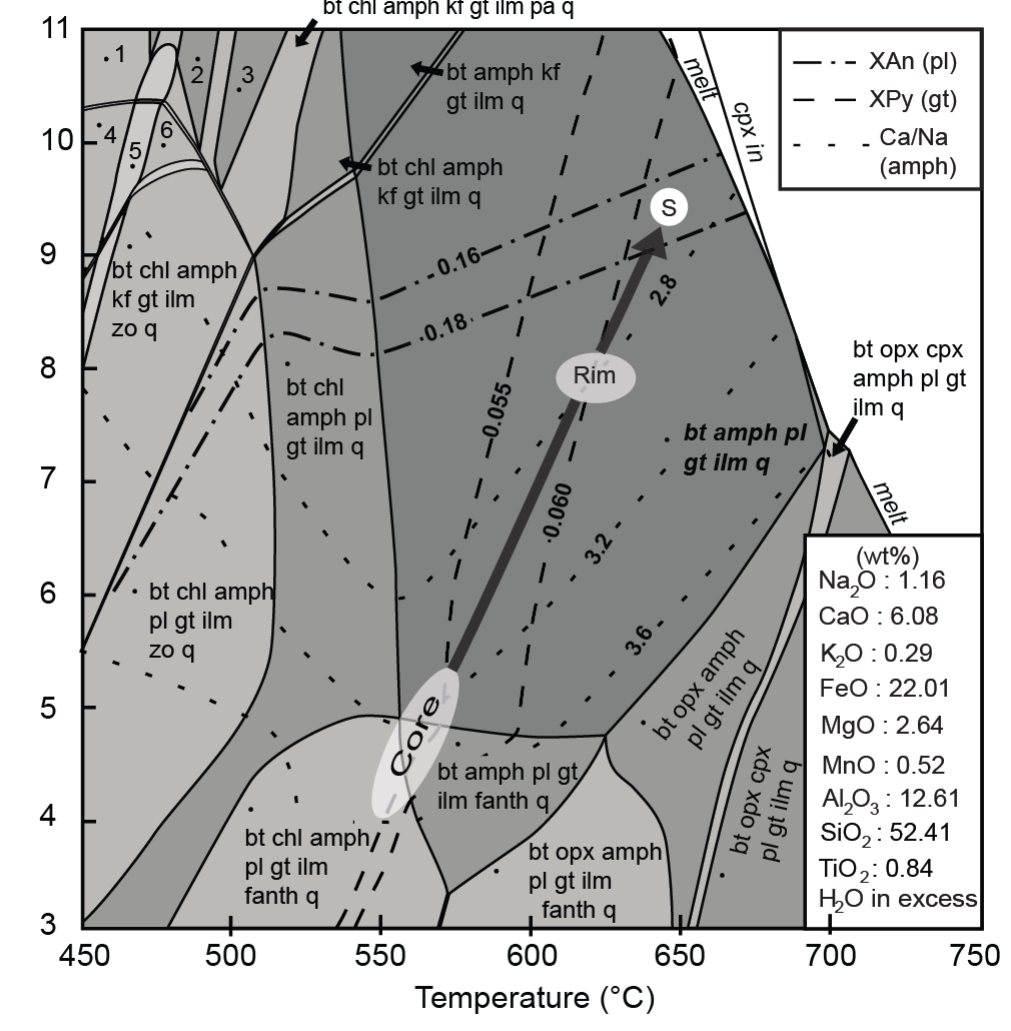

1.chl wm cpx gt ilm zo pa q $3 . \mathrm{bt} \mathrm{chl}$ amph gt ilm pa q $\quad$ 5.chl wm amph kf cpx gt ilm zo q

2.chl wm amph gt ilm pa q 4.chl wm kf cpx gt ilm zo q $6 . \mathrm{chl} w \mathrm{~m}$ amph $\mathrm{kf}$ gt ilm zo q

Figure 6:

$P-T$ pseudosections for the Silwana Amphibolites. The pseudosection is constructed in the model system TiNCKFMASH system, with water in excess. White circles and ellipses mark the fields with the best agreement between observed and calculated assemblages and mineral compositions (core, rim, S). The multivariant field designated in bold-italics correspond to the observed peak assemblage. The arrows define the $P-T$ vector inferred from petrological constraints. fanth $=$ ferro-anthophyllite, $p a=$ paragonite, zo $=$ zoisite.

\subsection{Murchison Unit}

The model multivariant field corresponding to the metamorphic assemblage of sample M1: Act $+\mathrm{Chl}+$ $\mathrm{Ab}+\mathrm{Ep}+\mathrm{Sph}+\mathrm{Q}\left(\right.$ Fig. 7a) constrains metamorphic $\mathrm{P}-\mathrm{T}$ conditions of $340-370^{\circ} \mathrm{C}$ at a wide pressure range from 1.3 to $5.8 \mathrm{kbar}$. The agreement between the measured and calculated actinolite composition restricts the metamorphic pressure conditions to $1.3-2.8$ kbar at $340-370{ }^{\circ} \mathrm{C}$ (hatched field in Fig. $7 \mathrm{a}$ ). However, it should be noted that clinozoisite (cz) instead of epidote has been calculated, due to the fact that the $\mathrm{Fe}^{3+}$ content was approximated to be 0 during the calculations (see Appendix A2). The observed 
$556 \mathrm{Mg} \#$ of chlorite falls in a $\mathrm{P}-\mathrm{T}$ space characterised by even lower temperatures of $240-300^{\circ} \mathrm{C}$ (not 557 shown). The latter may be indicative of chlorite (which is present in late-stage shear bands) crystallisation 558 and/or re-equilibration during retrograde cooling. In summary, the geobarometric constraints for sample 559 M1 point to a lower greenschist-facies metamorphism.

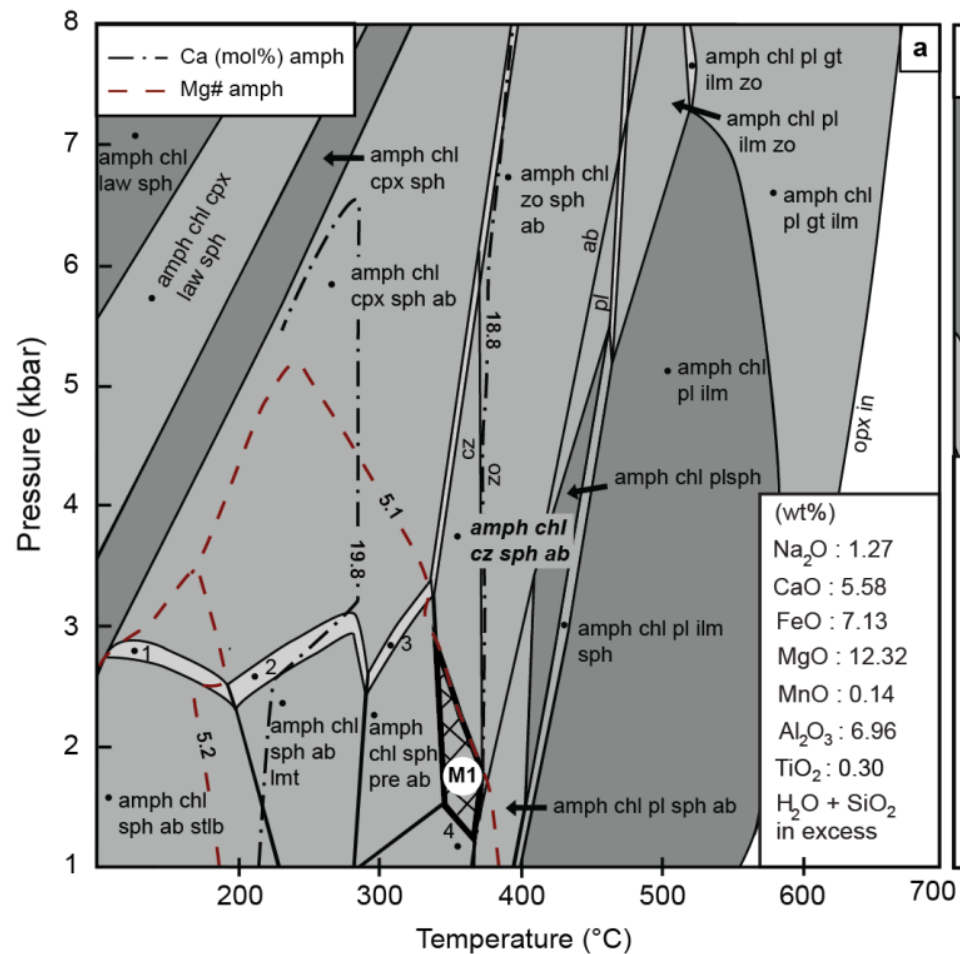

1. amph chl cpx sph ab stlb

2. amph chl cpx sph ab Imt
3. amph chl cpx sph pre ab

4. amph chl sph ab wrk

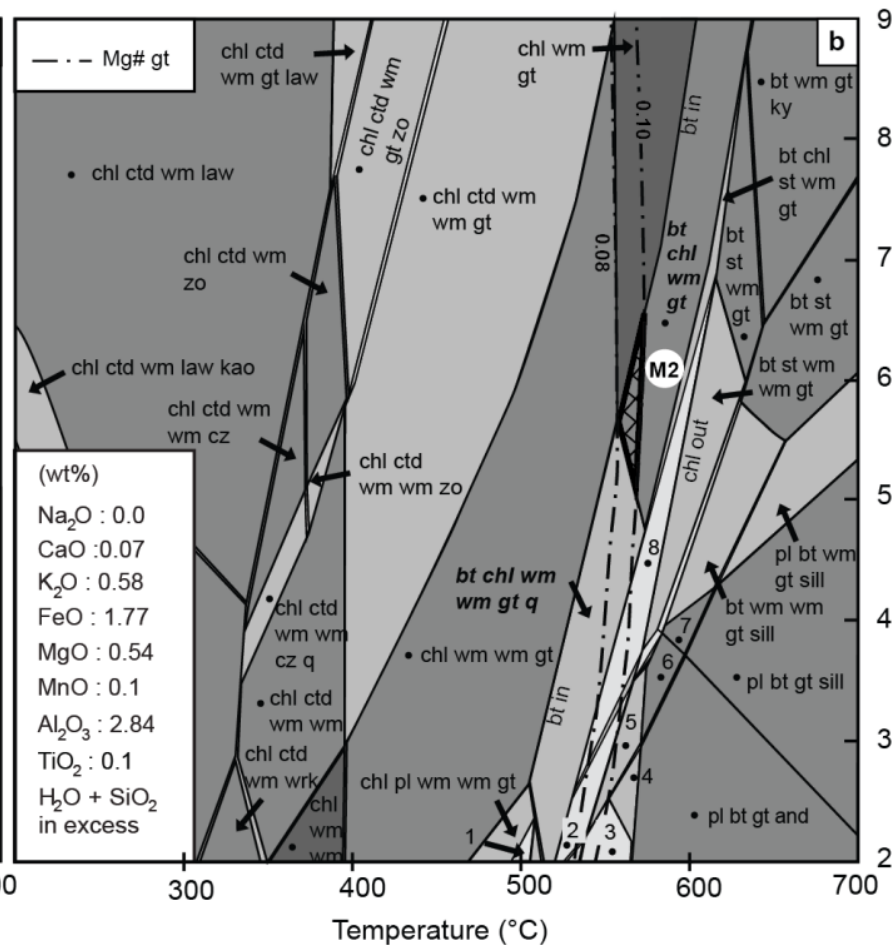

1. pl chl wm gt 2. bt chl wm wm gt and 3. pl bt chl gt and
5. bt chl wm gt and

6. bt wm gt and

4. pl bt chl gt and
7. bt wm gt sill

8. bt chl st wm wm gt

Figure 7:

$P$ - T pseudosections for rocks from the Murchison Unit. (a) Metabasite from the center of the Murchison unit, sample M1. (b) Garnet-bearing aluminous quartzite from the southern edge of the Murchison Unit. Hatched areas labelled M1 and M2 mark the fields with the best agreement between observed and calculated assemblages and mineral compositions. $W m=$ white mica, and $=$ andalusite, $z o=z o i s i t e, c z=$ clinozoisite, $a b=$ albite, pre $=$ prehnite, wrk $=$ wairakite, lmt $=$ laumontite, stlb $=$ stilbite, kao $=$ kaolinite.

The $\mathrm{P}-\mathrm{T}$ pseudosection constructed for the metapelite sample $\mathrm{M} 2$, containing the peak metamorphic assemblage (M2) $\mathrm{Gt}+\mathrm{Ms}+\mathrm{Bt}+\mathrm{Chl}+\mathrm{Qtz}$, indicates peak temperatures between 530 and $570{ }^{\circ} \mathrm{C}$, at pressures between 5.0 and $6.2 \mathrm{kbar}$ (hatched phase field in Fig. 7b). The peak metamorphic temperature conditions are constrained by two temperature-dependant field boundaries, the biotite-in and 
chlorite-out / staurolite-in phase boundaries, as well as by the the fit between modelled and measured

$574 \mathrm{Mg} \#$ of garnet (Fig. 7b). The finding of muscovite without other white micas in sample M2 furthermore requires peak pressure conditions between 5.0 and $6.2 \mathrm{kbars}$ at $550-570^{\circ} \mathrm{C}$. The metamorphic grade of sample M2 is somewhat higher than that of sample M1, at the transition between high T greenschist and low $\mathrm{P}$ amphibolite facies, but is significantly lower than that of the rocks from the La France Formation 578 and Silwana Amphibolites.

\section{Geochronology}

In order to constrain the timing of metamorphism and deformation in the MGB, LA-ICP-MS U-Pb dating was carried out on a syn-deformation granite intrusive in the Letaba Shear Zone (sample mur0982, see Fig. 2 for location). In addition, monazite and xenotime from the kyanite-bearing metapelite from the La France Formation (sample B) were dated.

The zircon grains were characterised by cathololuminescence imaging prior to analyses and were analysed on grain mounts, while monazite and xenotime $\mathrm{U}-\mathrm{Pb}$ analyses were carried out on a thin section, after their characterisation by back-scattered electron imaging. The results are shown in Table 3 and in Fig. 8. Analytical techniques and data processing methods are detailed in Appendix (A3).

\subsection{Zircons from magmatic rocks}

Twenty zircons from the syn-deformation granite sample mur0982 intrusive into the LSZ to the North of the belt, displaying an oscillatory magmatic zoning, were analysed. Nineteen out of twenty $\mathrm{U}-\mathrm{Pb}$ analyses plot along a discordia with an upper intercept at $2964 \pm 5 \mathrm{Ma}(\mathrm{MSWD}=5.4)$, whereas a xenocryst zircon 
599 grain (28110411d) yields a much older ${ }^{207} \mathrm{~Pb} /{ }^{206} \mathrm{~Pb}$ age of $3251 \pm 18 \mathrm{Ma}$ (Table3). The upper intercept age

600 is within error identical to a Concordia age (as of Ludwig, 1998) of $2964 \pm 8$ Ma (MSWD $=0.24$,

601 probability of concordance $=0.63, n=6$ ) (Fig. 8a, b). It is interpreted to reflect the timing of the syn-

602 tectonic granite emplacement. This interpretation is supported by the observation that the granite is

603 intrusive in the Letaba Shear Zone and shows a mylonitic foliation that is coplanar with the mylonitic

604 fabric of the greenschist-facies schists of the LSZ.

606 Table 3:

607 Top: U-Pb isotopic data obtained by LA-ICP-MS analyses carried out in GUF, and calculated ages from

608 monazite and xenotime from sample B. Bottom: U-Pb isotopic data obtained by LA-ICP-MS analyses

6099 carried out in Clermont-Ferrand and calculated ages from zircons from sample mur0982.

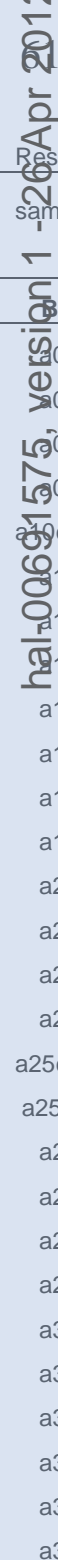

ssults of U-Pb LA-ICP-MS analyses of monazite (mnz) and xenotime (xno) carried out at Goethe University Frankfurt

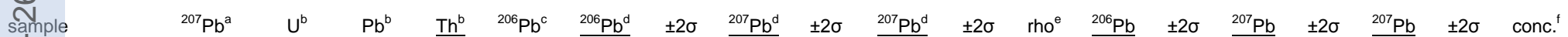

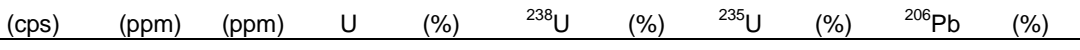

mnz 253119

$\mathrm{mnz} \quad 536981 \quad 3062$

$\mathrm{mnz} \quad 536981 \quad 3062$

$\mathrm{mnz} \quad 370826 \quad 2627$

$\mathrm{mnz} \quad 519077$

3342

$\begin{array}{lll}2900 & 21.1 & 0.57\end{array}$

$6600 \quad 11.8 \quad 0.12$

$0.4804 \quad 4.1$

12.54

$\begin{array}{lll}4100 & 7.7 & 1.07\end{array}$

0.5312

14.00

4.1

xno $\quad 1149852 \quad 4946$

xno $1255656 \quad 4462$

$\begin{array}{lll}5800 & 8.6 & 0.10\end{array}$

0.4852

2.6

2.1

0.1894

0.5

$\mathrm{mnz} \quad 630276 \quad 4092$

$\begin{array}{lll}3100 & 0.4 & 0.08\end{array}$

$0.5504 \quad 2.4$

$12.77 \quad 2.8$

0.1912

$0.7 \quad 0.95$

0.7

$.0 \quad 0.93$

5

$\mathrm{mnz}$

105973403

2700

$0.4 \quad 0.09$

$0.5562 \quad 8$

$\begin{array}{lll}14.53 & 2.5 & 0.1915\end{array}$

$0.8 \quad 0.95$

$\begin{array}{ll}1.6 & 0.98\end{array}$

8000

$9.9 \quad 0.10$

0.5249

16.11

0.2101

9.98

0.5122

$\mathrm{mnz} \quad 445663 \quad 4136$

$\mathrm{mnz} \quad 404074 \quad 2226$

$\mathrm{mnz} \quad 382514 \quad 2406$

7900

$8.9 \quad 0.08$

0.523

$\begin{array}{lll}13.4 & 8.25\end{array}$

$\begin{array}{ll}4.8 & 0.2033\end{array}$

$\begin{array}{ll}.9 & 0.92 \\ 0.5 & 0.97\end{array}$

$\begin{array}{lll}5300 & 13.9 & 0.19\end{array}$

0.5245

$\mathrm{mnz} \quad 448130 \quad 2403$

$\begin{array}{lll}4800 & 10.6 & 0.43\end{array}$

0.5344

xno $1314118 \quad 6201$

$\begin{array}{lll}6000 & 13.8 & 0.35\end{array}$

0.5410

$\mathrm{mnz} \quad 118475$

661

$\begin{array}{lll}3500 & 0.2 & 0.05\end{array}$

0.5305

$\mathrm{mnz} \quad 268818 \quad 2076$

$\begin{array}{lll}2200 & 24.6 & 0.92\end{array}$

0.4411

$\begin{array}{llll}5100 & 13.5 & 0.13 & 0.5268\end{array}$

$5200 \quad 11.1 \quad 0.11$

0.5416

$\begin{array}{lll}10000 & 17.4 & 0.10\end{array}$

0.5697

$\begin{array}{lll}6200 & 14.6 & 0.10\end{array}$

0.5254

$2.8 \quad 13.85$

$1.3 \quad 1.00$

3.85

13.71

14.09

$14.24 \quad 2.7$

14.00

11.26

$\begin{array}{llllll}3.7 & 13.91 & 3.7 & 0.1916 & 0.4 & 0.99 \\ 2.0 & 14.39 & 2.4 & 0.1928 & 1.2 & 0.86\end{array}$

$\begin{array}{llllll}3.7 & 13.91 & 3.7 & 0.1916 & 0.4 & 0.99 \\ 2.0 & 14.39 & 2.4 & 0.1928 & 1.2 & 0.86\end{array}$

$0.1860 \quad 1$

90.1921

$\begin{array}{ll}0.7 & 0.97\end{array}$

0.1896

$0.5 \quad 0.97$

$\mathrm{mnz} \quad 897089 \quad 3654$

$\mathrm{mnz}$

509831

2393

$\begin{array}{lll}1600 & 9.3 & 0.74\end{array}$

$0.4560 \quad 6.2$

mnz $358562 \quad 2024$

$\begin{array}{lll}\mathrm{mnz} & 381917 \quad 2499\end{array}$

mnz $585399 \quad 3991$

xno $1764628 \quad 8893$

xno $1374114 \quad 8166$

$\mathrm{mnz} \quad 52970 \quad 149$

mnz $\quad 415719 \quad 2602$

$\begin{array}{lll}4900 & 14.3 & 0.10\end{array}$

$0.5352 \quad 1.6$

$\begin{array}{lll}5700 & 12.2 & 0.39\end{array}$

$\begin{array}{lll}8300 & 10.5 & 0.24\end{array}$

$\begin{array}{lll}5200 & 0.3 & 0.03\end{array}$

$\begin{array}{lll}4700 & 0.2 & 0.03\end{array}$

0.4678

$0.5010 \quad 2.4$

0.5292

0.5338

$\begin{array}{lll}550 & 20.0 & 0.66\end{array}$

$0.5146 \quad 6.3$

$\mathrm{mnz} \quad 519221 \quad 2744$

$\begin{array}{lll}100 & 10.7 & 1.14\end{array}$

$0.5317 \quad 2.4$

mnz 174257

741

$\begin{array}{lll}2800 & 24.4 & 0.92\end{array}$

$0.5319 \quad 2.4$

0.4369

$\begin{array}{lllll}16.67 & 2.1 & 0.2122 & 0.7 & 0.95\end{array}$

$\begin{array}{lllll}13.86 & 2.0 & 0.1913 & 0.7 & 0.94\end{array}$

$\begin{array}{lllll}12.09 & 6.4 & 0.1922 & 1.4 & 0.98\end{array}$

$\begin{array}{lllll}13.95 & 1.7 & 0.1890 & 0.4 & 0.97\end{array}$

$\begin{array}{lllll}12.18 & 3.1 & 0.1888 & 0.8 & 0.96\end{array}$

$13.48 \quad 2.5$

$14.04 \quad 1.8$

$14.20 \quad 2.6$

13.27

$13.92 \quad 2.5$

$\begin{array}{llll}2.5 & 0.1899 & 0.8 & 0.95\end{array}$

$\begin{array}{llllll}1.02 & 2.5 & 0.1912 & 0.6 & 0.97\end{array}$ 
Within run background-corrected mean ${ }^{207} \mathrm{~Pb}$ signal in cps (counts per second).

${ }^{\mathrm{b}} \mathrm{U}$ and $\mathrm{Pb}$ content and $\mathrm{Th} / \mathrm{U}$ ratio were calculated relative to $\mathrm{GJ}-1$ reference zircon.

percentage of the common $\mathrm{Pb}$ on the ${ }^{206} \mathrm{~Pb}$. b.d. = below dectection limit.

corrected for background, within-run $\mathrm{Pb} / \mathrm{U}$ fractionation (in case of ${ }^{206} \mathrm{~Pb} /{ }^{238} \mathrm{U}$ ) and common $\mathrm{Pb}$ using Stacy and Kramers

(1975) model Pb composition and

subsequently normalised to GJ-1 (ID-TIMS value/measured value); ${ }^{20 /} \mathrm{Pb} /{ }^{235} \mathrm{U}$ calculated using

${ }^{207} \mathrm{~Pb} /{ }^{206} \mathrm{~Pb} /\left({ }^{238} \mathrm{U} /{ }^{206} \mathrm{~Pb} * 1 / 137.88\right)$

${ }^{e}$ rho is the ${ }^{206} \mathrm{~Pb} /{ }^{238} \mathrm{U} /{ }^{207} \mathrm{~Pb} /{ }^{235} \mathrm{U}$ error correlation coefficient.

${ }^{f}$ degree of concordance $={ }^{206} \mathrm{~Pb} /{ }^{238} \mathrm{U}$ age $/{ }^{207} \mathrm{~Pb} /{ }^{206} \mathrm{~Pb}$ age $\times 100$

611

Results of U-Pb LA-ICP-MS analyses of sample mur0982 carried out in Clermont Ferrand

\begin{tabular}{|c|c|c|c|c|c|c|c|c|c|c|c|c|c|c|c|c|c|c|c|}
\hline & & $\begin{array}{r}{ }^{207} \mathrm{~Pb}^{\mathrm{a}} \\
(\mathrm{cps}) \\
\end{array}$ & $\begin{array}{c}U^{b} \\
(p p m) \\
\end{array}$ & $\begin{array}{c}\mathrm{Pb}^{\mathrm{c}} \\
(\mathrm{ppm}) \\
\end{array}$ & $\frac{\mathrm{Th}^{\mathrm{b}}}{\mathrm{U}}$ & $\frac{{ }^{206} \mathrm{~Pb}^{\mathrm{d}}}{{ }^{238} \mathrm{U}}$ & $\begin{array}{l} \pm 2 \sigma \\
(\%)\end{array}$ & $\frac{{ }^{207} \mathrm{~Pb}^{\mathrm{d}}}{{ }^{235} \mathrm{U}}$ & $\begin{array}{l} \pm 2 \sigma \\
(\%)\end{array}$ & $\frac{{ }^{207} \mathrm{~Pb}^{\mathrm{d}}}{{ }^{206} \mathrm{~Pb}}$ & $\begin{array}{l} \pm 2 \sigma \\
(\%)\end{array}$ & rho $^{\mathrm{e}}$ & $\frac{{ }^{206} \mathrm{~Pb}}{{ }^{238} \mathrm{U}}$ & $\begin{array}{l} \pm 2 \sigma \\
(\mathrm{Ma})\end{array}$ & $\frac{{ }^{207} \mathrm{~Pb}}{{ }^{235} \mathrm{U}}$ & $\begin{array}{l} \pm 2 \sigma \\
(\mathrm{Ma})\end{array}$ & $\frac{{ }^{207} \mathrm{~Pb}}{{ }^{206} \mathrm{~Pb}}$ & $\begin{array}{l} \pm 2 \sigma \\
(\mathrm{Ma})\end{array}$ & $\begin{array}{c}\text { conc. }^{f} \\
(\%) \\
\end{array}$ \\
\hline \multicolumn{20}{|l|}{ mur0982 } \\
\hline 05110411d & $\mathrm{zr}$ & 8180 & 39 & 23 & 0.20 & 0.5956 & 2.0 & 17.74 & 2.1 & 0.2161 & 2.2 & 0.94 & 3012 & 48 & 2976 & 21 & 2952 & 35 & 102 \\
\hline 06110411d & $\mathrm{zr}$ & 42538 & 408 & 126 & 0.38 & 0.3051 & 2.0 & 8.85 & 2.0 & 0.2103 & 2.1 & 0.97 & 1717 & 30 & 2323 & 18 & 2908 & 33 & 59 \\
\hline 07110411d & $\mathrm{zr}$ & 16914 & 98 & 47 & 0.24 & 0.4921 & 2.0 & 14.69 & 2.1 & 0.2165 & 2.1 & 0.96 & 2580 & 42 & 2796 & 20 & 2955 & 34 & 87 \\
\hline $\mathrm{N}^{08110411 d}$ & $\mathrm{zr}$ & 13025 & 73 & 35 & 0.20 & 0.5011 & 2.0 & 15.17 & 2.2 & 0.2195 & 2.3 & 0.92 & 2619 & 44 & 2826 & 21 & 2977 & 36 & 88 \\
\hline $\bar{\sigma}^{09110411 d}$ & $\mathrm{zr}$ & 55162 & 669 & 157 & 0.47 & 0.2496 & 2.0 & 7.08 & 2.0 & 0.2058 & 2.1 & 0.97 & 1436 & 25 & 2122 & 18 & 2873 & 34 & 50 \\
\hline $\mathrm{N}_{10110411 d}$ & $\mathrm{zr}$ & 11560 & 67 & 32 & 0.32 & 0.5004 & 2.0 & 14.98 & 2.1 & 0.2171 & 2.2 & 0.94 & 2615 & 43 & 2814 & 20 & 2959 & 35 & 88 \\
\hline 의11110411d & $\mathrm{zr}$ & 21853 & 318 & 70 & 0.53 & 0.2313 & 2.0 & 5.96 & 2.1 & 0.187 & 2.2 & 0.94 & 1341 & 24 & 1970 & 19 & 2716 & 36 & 49 \\
\hline $0^{12110411 d}$ & $\mathrm{zr}$ & 11361 & 54 & 32 & 0.20 & 0.6084 & 2.0 & 18.27 & 2.2 & 0.2177 & 2.3 & 0.92 & 3064 & 50 & 3004 & 21 & 2964 & 36 & 103 \\
\hline $\mathrm{N}_{15110411 d}$ & $\mathrm{zr}$ & 15607 & 79 & 44 & 0.23 & 0.5785 & 2.0 & 17.42 & 2.1 & 0.2184 & 2.2 & 0.94 & 2943 & 48 & 2958 & 21 & 2969 & 35 & 99 \\
\hline${ }^{16110411 d}$ & $\mathrm{zr}$ & 22058 & 142 & 63 & 0.35 & 0.4593 & 2.0 & 13.75 & 2.1 & 0.2171 & 2.1 & 0.95 & 2437 & 41 & 2733 & 20 & 2960 & 34 & 82 \\
\hline$\frac{\subset}{}$ & $\mathrm{zr}$ & 20140 & 121 & 56 & 0.25 & 0.4916 & 2.0 & 14.82 & 2.1 & 0.2186 & 2.1 & 0.94 & 2578 & 43 & 2804 & 20 & 2971 & 34 & 87 \\
\hline$-\frac{1}{\mathscr{C}} 18110411 \mathrm{~d}$ & $\mathrm{zr}$ & 12592 & 91 & 36 & 0.29 & 0.4169 & 2.0 & 12.36 & 2.2 & 0.2151 & 2.2 & 0.93 & 2246 & 39 & 2633 & 21 & 2944 & 35 & 76 \\
\hline$\underbrace{1} 19110411 d$ & $\mathrm{zr}$ & 14013 & 74 & 39 & 0.18 & 0.5605 & 2.0 & 16.91 & 2.2 & 0.2188 & 2.2 & 0.94 & 2869 & 47 & 2930 & 21 & 2972 & 35 & 97 \\
\hline $20110411 d$ & $\mathrm{zr}$ & 9774 & 85 & 28 & 0.73 & 0.3431 & 2.1 & 10.32 & 2.2 & 0.2182 & 2.3 & 0.92 & 1902 & 34 & 2464 & 21 & 2968 & 36 & 64 \\
\hline $21110411 d$ & $\mathrm{zr}$ & 9362 & 49 & 26 & 0.18 & 0.5792 & 2.1 & 17.40 & 2.2 & 0.2179 & 2.2 & 0.92 & 2945 & 49 & 2957 & 22 & 2966 & 36 & 99 \\
\hline ك22110411d & $\mathrm{zr}$ & 10061 & 87 & 29 & 0.22 & 0.3513 & 2.1 & 10.53 & 2.3 & 0.2175 & 2.2 & 0.92 & 1941 & 35 & 2483 & 21 & 2962 & 36 & 66 \\
\hline ब25110411d & $\mathrm{zr}$ & 12745 & 66 & 36 & 0.21 & 0.5848 & 2.1 & 17.65 & 2.3 & 0.2189 & 2.3 & 0.91 & 2968 & 49 & 2971 & 22 & 2972 & 36 & 100 \\
\hline & $\mathrm{zr}$ & 11260 & 59 & 32 & 0.22 & 0.5851 & 2.1 & 17.58 & 2.3 & 0.2179 & 2.3 & 0.91 & 2969 & 49 & 2967 & 22 & 2966 & 36 & 100 \\
\hline$\frac{\mathrm{I}}{\sigma^{2}} 27110411 \mathrm{~d}$ & $\mathrm{zr}$ & 8942 & 47 & 26 & 0.21 & 0.5872 & 2.1 & 17.52 & 2.4 & 0.2165 & 2.3 & 0.89 & 2978 & 50 & 2964 & 23 & 2955 & 37 & 101 \\
\hline$\subset_{28110411 d}$ & $\mathrm{zr}$ & 21485 & 105 & 55 & 0.35 & 0.5329 & 2.1 & 19.16 & 2.3 & 0.2607 & 2.3 & 0.91 & 2754 & 47 & 3050 & 22 & 3251 & 35 & 85 \\
\hline $29110411 d$ & $\mathrm{zr}$ & 25554 & 211 & 76 & 0.28 & 0.3868 & 2.1 & 11.33 & 2.3 & 0.2123 & 2.3 & 0.90 & 2108 & 38 & 2550 & 22 & 2924 & 37 & 72 \\
\hline
\end{tabular}

${ }^{a}$ Within run background-corrected mean ${ }^{207} \mathrm{~Pb}$ signal in cps (counts per second).

${ }^{\mathrm{b}} \mathrm{U}$ and $\mathrm{Pb}$ content and $\mathrm{Th} / \mathrm{U}$ ratio were calculated relative to $\mathrm{GJ}-1$ reference zircon.

${ }^{c}$ percentage of the common $\mathrm{Pb}$ on the ${ }^{206} \mathrm{~Pb}$. b.d. = below dectection limit.

corrected for background, within-run $\mathrm{Pb} / \mathrm{U}$ fractionation (in case of ${ }^{206} \mathrm{~Pb} /{ }^{238} \mathrm{U}$ ) and common $\mathrm{Pb}$ using Stacy and Kramers

(1975) model $\mathrm{Pb}$ composition and

subsequently normalised to GJ-1 (ID-TIMS value/measured value); ${ }^{20 /} \mathrm{Pb} /{ }^{235} \mathrm{U}$ calculated using

${ }^{207} \mathrm{~Pb} /{ }^{206} \mathrm{~Pb} /\left({ }^{238} \mathrm{U} /{ }^{206} \mathrm{~Pb}^{*} 1 / 137.88\right)$

${ }^{e}$ rho is the ${ }^{206} \mathrm{~Pb} /{ }^{238} \mathrm{U} /{ }^{207} \mathrm{~Pb} /{ }^{235} \mathrm{U}$ error correlation coefficient

${ }^{\mathrm{f}}$ degree of concordance $={ }^{206} \mathrm{~Pb} /{ }^{238} \mathrm{U}$ age $/{ }^{207} \mathrm{~Pb} /{ }^{206} \mathrm{~Pb}$ age $\times 100$

612

$613 \quad 5.2$ Monazite and xenotime dating

614

615 A total of $31 \mathrm{U}-\mathrm{Th}-\mathrm{Pb}$ laser spot analyses were carried out on 18 monazite and 3 xenotime grains found in

616 the La France micaschists, sample B. The grains yielded two sets of concordant ages (Fig. 8c). Most 
617 grains, which are intergrown with the matrix micas, yielded a concordant $\mathrm{U}-\mathrm{Pb}$ age of $2752 \pm 7 \mathrm{Ma}$.

618 Xenotime and a monazite inclusions in kyanite porphyroblasts yielded much older concordant U-Pb ages 619 of $2906 \pm 26$ and $2923 \pm 11$ Ma, respectively (grey ellipses in Fig. 8c). The stepwise decrease of the time 620 resolved, common $\mathrm{Pb}$ corrected ${ }^{207} \mathrm{~Pb} /{ }^{206} \mathrm{~Pb}$ signal during the analysis of the monazite inclusion in kyanite 621 indicated that this grain was zoned. The drop of ${ }^{207} \mathrm{~Pb} /{ }^{206} \mathrm{~Pb}$ signal corresponds to an age decrease from $6222923 \pm 11$ Ma to $2754 \pm 11$ Ma (Fig. 8f). A possible explanation to this result is that kyanite and monazite 623 formed at ca. $2923 \mathrm{Ma}$ or prior to it, and that the monazite inclusion in kyanite subsequently underwent 624 partial alteration and resetting at ca. $2754 \mathrm{Ma}$, simultaneous to the formation or complete re625 crystallisation of matrix monazite and xenotime. We therefore suggest that the ca. 2923 Ma age represents a minimal age for the metamorphic peak in the La France Formation.
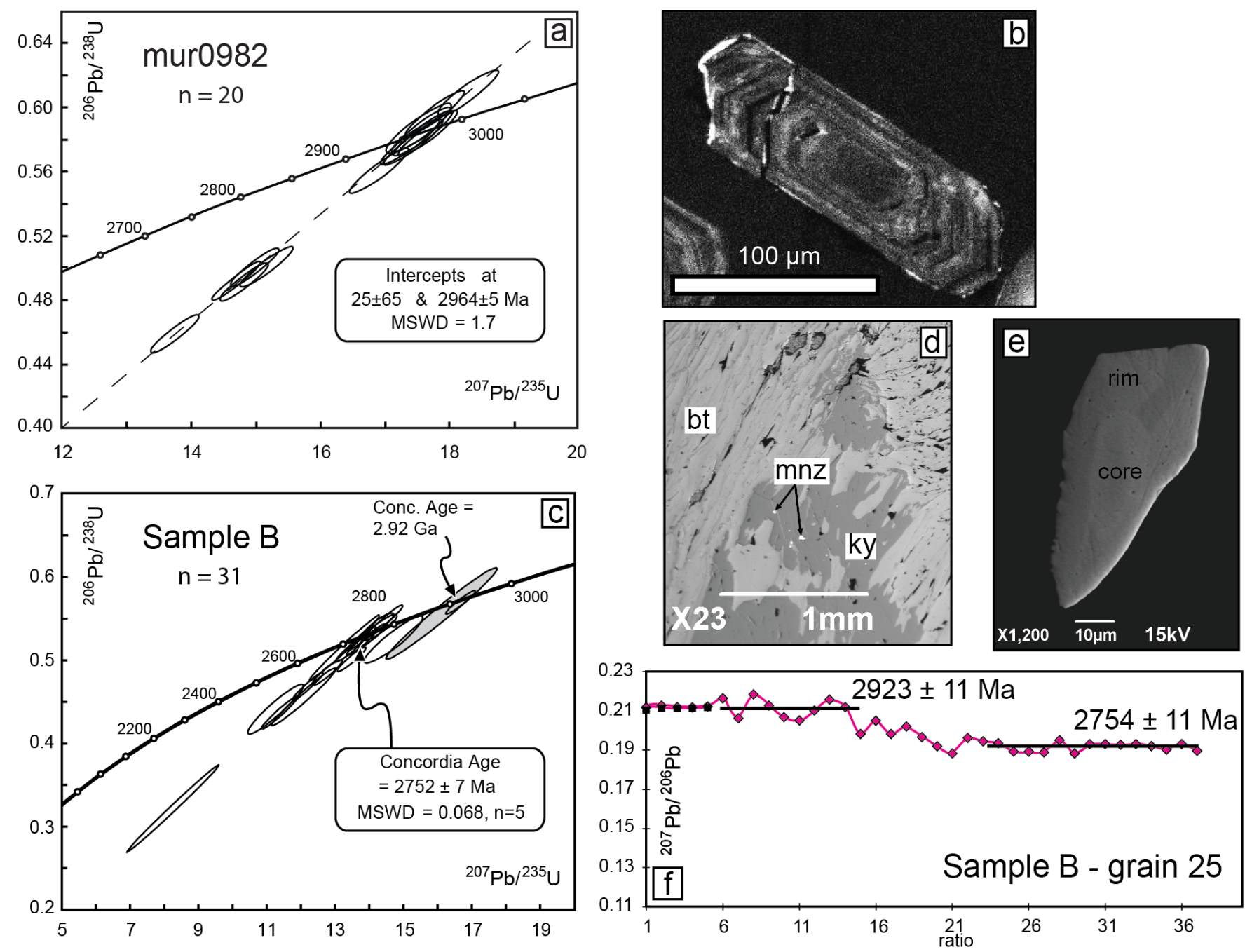

628 Figure 8:

Results of U-Pb LA-ICP-MS dating of zircon, monazite and xenotime from the La France Formation. 
630 (a) Concordia diagram with results of $U-P b$ zircon dating of the granitoid sample mur0982 from the 631 Letaba Shear Zone. An upper intercept age of $2966.7 \pm 7.1$ Ma was obtained. (b) Cathodoluminescence image of a zircon of sample mur0982. (c) Concordia diagram showing results of monazite and xenotime analysis of sample B of the La France Formation, with concordant ages at $2752 \pm 7$. (d) BSE image of monazite inclusions in a kyanite porphyroblast in sample B. (e) BSE image of a monazite inclusion in

635 kyanite (sample B) revealing a complex zonation.

636 g) Time resolved ${ }^{207} \mathrm{~Pb}{ }^{206} \mathrm{~Pb}$ signal obtained from a monazite inclusion in kyanite (mnz grain 25 - Table 637 3). Note the stepwise decrease of the ${ }^{207} \mathrm{~Pb} /{ }^{206} \mathrm{~Pb}$ signal, corresponding to an age decrease from $2923 \pm$ 63811 Ma to $2754 \pm 11$ Ma (2 sigma).

639

640

\section{Discussion}

\subsection{Metamorphic conditions and geothermal gradients}

The results of our $\mathrm{P}-\mathrm{T}$ modelling reveal that the three investigated tectono-metamorphic units of the MGB underwent contrasted metamorphic evolutions. The volcano-sedimentary rocks of the Murchison Unit, that form the central part of the MGB, underwent metamorphism in the lower-greenschist to loweramphibolite facies, at $\mathrm{P}-\mathrm{T}$ conditions not exceeding 5-6.2 kbar and 530-570 ${ }^{\circ} \mathrm{C}$; peak metamorphic conditions being highly variable within this unit. In contrast, the La France Formation, on the southern edge of the MGB, underwent high grade amphibolite-facies metamorphism at conditions of $8-9$ kbars, and temperatures of $600-650{ }^{\circ} \mathrm{C}$, corresponding to higher-amphibolite facies conditions. They subsequently underwent near-isothermal decompression to under $6.2 \mathrm{kbar}$, with temperature between 600 and $660^{\circ} \mathrm{C}$, followed by cooling to $570-610^{\circ} \mathrm{C}$, at pressures in excess of $5 \mathrm{kbar}$. The Silwana Amphibolites sliver, on the north-western edge of the MGB, experienced a metamorphic overprint in the upper amphibolite facies under $\mathrm{P}-\mathrm{T}$ conditions of $8.7-10 \mathrm{kbars}, 630-670^{\circ} \mathrm{C}$. Rocks of both units record a prograde pressure-temperature increase from about $4.5-5.5 \mathrm{kbars}$ at $520-570^{\circ} \mathrm{C}$ towards the metamorphic peak. Furthermore, rocks of the La France Formation additionally provide evidence for a 
complex retrograde $\mathrm{P}-\mathrm{T}$ history, characterised by near-isothermal decompression from $9.0-6.8$ to $<6$ kbar at $600-660{ }^{\circ} \mathrm{C}$, followed by a nearly-isobaric cooling from $620-650{ }^{\circ} \mathrm{C}$ to $570-610^{\circ} \mathrm{C}$ at about 5.5 kbar, accompanied by a secondary $\mathrm{H}_{2} \mathrm{O}$-rich fluid enrichment.

661

662

663

664

665

666

667

N

Peak $\mathrm{P}-\mathrm{T}$ conditions for the La France supracrustals and the Silwana Amphibolites require a burial to mid-crustal levels, at depths of $27-30 \mathrm{~km}$ and $29-33 \mathrm{~km}$ respectively. Bearing in mind that the pressures determined from peak assemblages are in fact minimal pressures due to possible reequilibration of the thermodynamic systems along the high-grade portions of the retrograde path, these values represent minimal burial depths. Therefore, the La France Formation and the Silwana Amphibolites underwent metamorphism along fairly similar minimal apparent geothermal gradients of $19-24^{\circ} \mathrm{C} / \mathrm{km}$. Furthermore, a steep prograde $\mathrm{P}-\mathrm{T}$ vector inferred for rocks from both formations, suggesting a fast burial. In contrast, much lower peak $\mathrm{P}-\mathrm{T}$ conditions of $5-6.2 \mathrm{kbar}$ and $550-570^{\circ} \mathrm{C}$ for sample M2 indicate that rocks of the Murchison Unit were buried at shallower depths of $16-20 \mathrm{~km}$, along an apparent geotherm of $27-34{ }^{\circ} \mathrm{C} / \mathrm{km}$. The peak $\mathrm{P}-\mathrm{T}$ conditions of metabasite sample $\mathrm{M} 1$ are even lower and require even higher apparent geotherms $\left(40-80^{\circ} \mathrm{C} / \mathrm{km}\right)$. The reasons for the different peak $\mathrm{P}-\mathrm{T}$ conditions of the investigated rocks of Murchison Unit are not entirely clear. Apart from the fact that the peak pressures are not well constrained, in particular for sample M1, the enormous temperature differences could reflect either a metamorphic array (e.g. England \& Thompson, 1984), whereby different slivers has reached different peak conditions at different times or, alternatively, a metamorphic gradient caused by magma intrusions within the MGB. A less likely option is that the enormous temperature difference represents an artefact of the used thermodynamic calculation method. If the latter holds true, the $\mathrm{P}-\mathrm{T}$ results obtained from the metapelitic rocks are considered to be more appropriate than those from the metabasite, since thermodynamic activity models for metapelite phases are more robust and less sensitive to slight variations in $\mathrm{Na}, \mathrm{Ti}$ and $\mathrm{Fe}^{3+}$ than those for metabasite phases, e.g. amphiboles (see Dale et al., 2005; Diener et al. 2007; Diener and Powell, 2010).

It is interesting to note that the maximum peak $\mathrm{P}-\mathrm{T}$ conditions obtained for the Murchison Unit 
684 (5.0-6.2 kbars at 530-570 ${ }^{\circ} \mathrm{C}$ ) overlap with those inferred from the retrograde $\mathrm{P}-\mathrm{T}$ evolution of the La 685 France Formations (assemblage B3). Despite this coincidence, it remains unclear, whether the identical $686 \mathrm{P}-\mathrm{T}$ conditions in both units were reached at the same time, meaning that prograde heating in the 687 Murchison Unit ceased while rocks of the La France Formation underwent isothermal decompression. In 688 any case, our results show that the three tectono-metamorphic units of the MGB were buried along 689 different apparent geotherms, at different crustal depths, and experienced contrasted metamorphic 690 evolutions before being juxtaposed.

\subsection{Timing of the evolution of the $M G B$}

A maximum age for metamorphism in the Murchison Unit is provided by the youngest (meta)volcanic rocks of the Rubbervale Formation of the MGB, dated at ca. 2.97 Ga (Brandl et al. 1996, Poujol et al. 1997, Poujol 2001). This age is identical within errors to the crystallisation age measured for the syndeformation granitoid intrusive in the Letaba Shear Zone. It also is indistinguishable from the crystallisation ages of small granitoid bodies emplaced both along the Antimony Line $(2970 \pm 15 \mathrm{Ma}$ Malati Pump granodiorite, Poujol et al. 1997), and to the south of the MGB (2969 \pm 17 Ma Discovery granite, Poujol 2001). However, it is significantly older that the U-Pb ages of $2752 \pm 7 \mathrm{Ma}$, and rarely of 2910-2920 Ma, obtained from the monazites and xenotimes of the La France micaschists. The older ages of ca. $2.92 \mathrm{Ga}$ which were only obtained from monazite or xenotime inclusions in kyanite, are interpreted to reflect a minimum age for peak metamorphism in the La France Formation. It is worth noting that these ages are within error identical to the emplacement age of the post-deformation Maranda Granite which intruded the southern part of the MGB at $2901 \pm 20$ Ma (Poujol et al., 1996), pointing to a possible synchronism of magmatism and metamorphism. The younger monazite and xenotime age of $2752 \pm 7 \mathrm{Ma}$ may results from re-activation of the MGB related to thermal processes in the Rooiwater Complex of the MGB (minimal intrusion ages of $2740 \pm 4$ Ma: Poujol et al., 1996), or in the Pietersburg Greenstone Belt (intrusion of the Turfloop granite at ca. $2780 \mathrm{Ma}$; Henderson et al., 2000). 


\subsection{Deformation localisation along major tectonic breaks}

713

The break in metamorphic conditions between the Silwana Amphibolites and the Murchison Unit greenschists requires a 9-23 km vertical displacement across the Letaba Shear Zone. Strain increases sharply from moderately deformed greenschists of the Murchison Unit to intensely sheared mylonites, to the amphibolitic gneiss of the Silwana Amphibolites, Furthermore, there is a marked change in deformation patterns across the shear zone, with a high-grade metamorphic flattening fabric, that formed during prograde metamorphism, in the Silwana Amphibolites, and low grade greenschist-facies mylonitic fabric, consistent with a sinistral strike-slip deformation, dominating in the Murchison Unit schists. The fabrics of the Letaba Shear Zone provide evidence for a general transpressive tectonic setting with a topto-the-south transport. The structures observed in the Letaba Shear Zones suggest that the Silwana Amphibolites, formed at a low crustal level, were juxtaposed to the greenschist- to lower amphibolitefacies rocks of the Murchison Unit along a transpressive shear zone, that was activated due to sustained crustal shortening in a general N-S direction, and that accommodated a large vertical displacement. As crustal shortening and thickening were ongoing, the tectonic regime may have shifted from transpression with a strong reverse component and a top-to-the-south directed transport, to strike-slip shearing. Locally, conjugated SE-trending shear zones were activated together with the predominant NE-trending structures. This late stage of tectonic activity was accompanied by the intrusion of syntectonic granitoids in the Letaba Shear Zone at $2967 \pm 7 \mathrm{Ma}$. These granitoids intruded prior to or during the sinistral slip under greenschist-facies conditions, as is well reflected by the S-C fabrics they display.

The La France Fault displays a number of similarities with the Letaba Shear Zone. It localises an important amount of deformation that accounts for a large vertical displacement of 7-20 kilometres. The fault zone also develops tectonic fabrics consistent with a general transpressive, sinistral regime and a 
top-to-the-south transport direction. Deformation in the La France Formation shows patterns that are not seen elsewhere in the MGB. Deformation in the fault zone can be correlated with the $\mathrm{D}_{3}$ deformation within the La France Formation, which is characterised by crenulations and small-wavelength open folds with shallow dipping axes. It post-dates the prograde $\mathrm{P}-\mathrm{T}$ evolution of the La France Formation during the $\mathrm{D}_{1}$ and $\mathrm{D}_{2}$ deformation events. The structures of both shear zones illustrate a north-overriding-south relation.
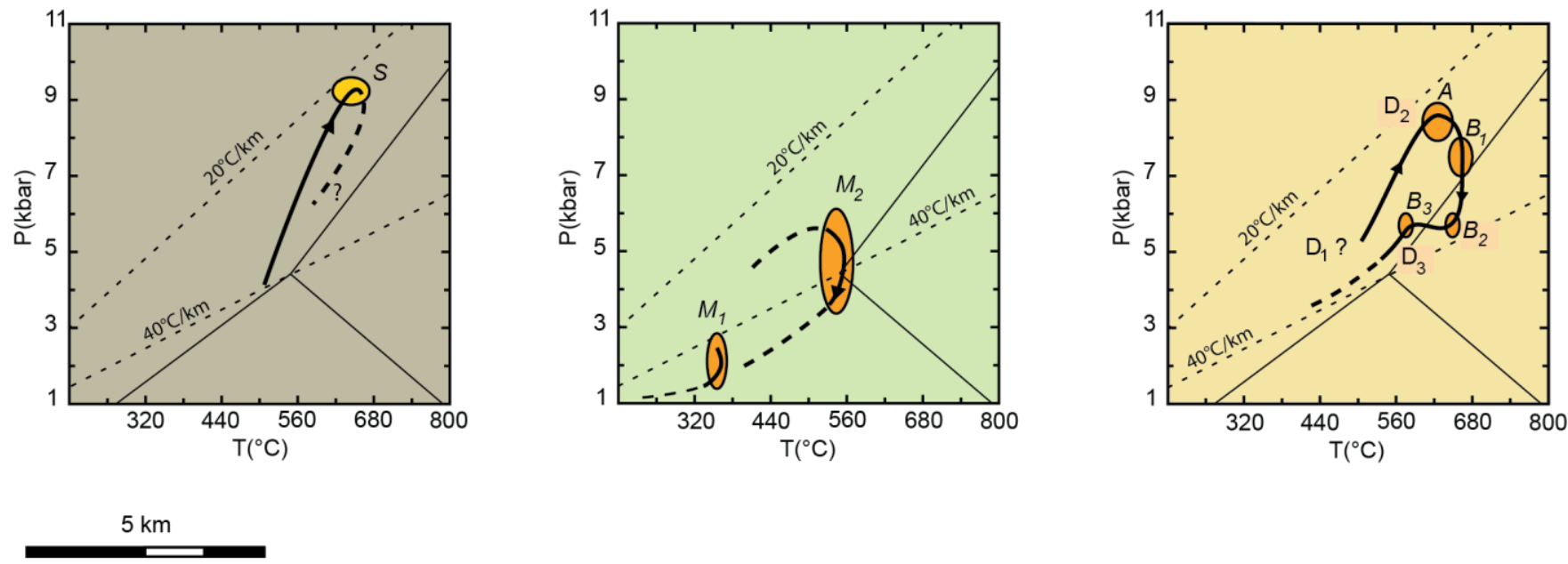

$\mathrm{N}$

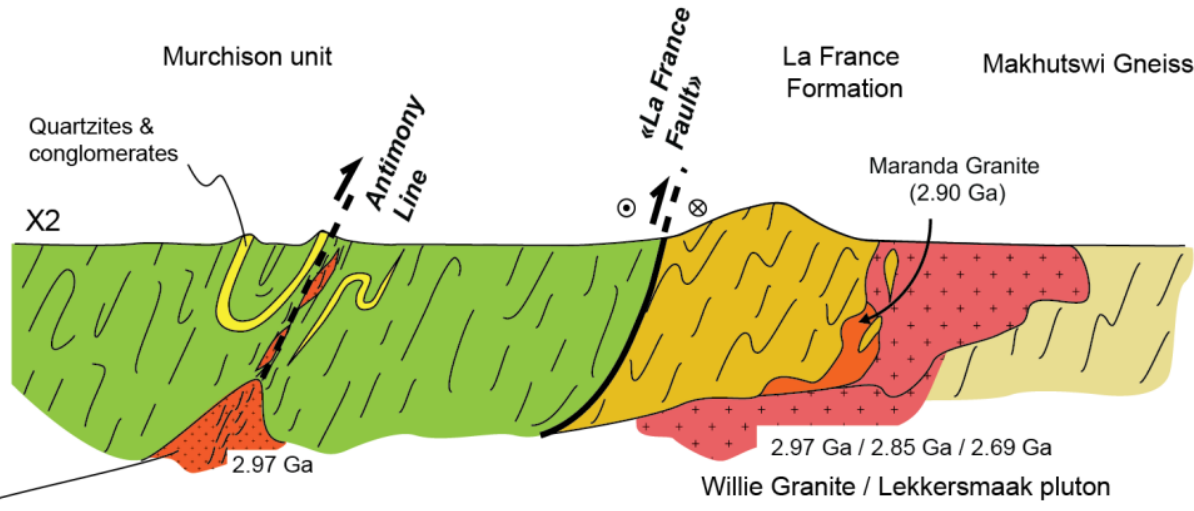

Syn-tectonic

Willie Granite / Lekkersmaak pluton

Groot Letaba Gneiss

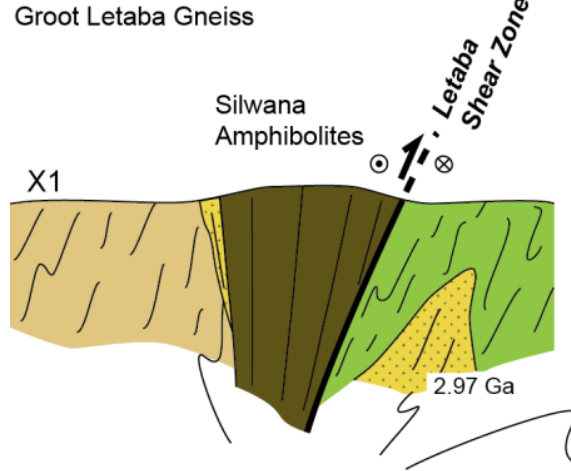

granitoïd intrusions

Figure 9:

Interpretative cross-section of the MGB. The MGB has an asymmetric structure, and structural units with distinct metamorphic P-T evolutions (see P-T diagrams) are juxtaposed along shear zones. The MGB is intruded by both syn-tectonic granitoids at $2.97 \mathrm{Ga}$ and by late-stage granitoids as from $2.90 \mathrm{Ga}$. Profile lines labelled $x 1$ and $x 2$ are located on Fig. 2. Ellipses in the $P-T$ diagrams indicate peak metamorphic and retrograde conditions obtained in this study.

Dark solid curves represent $P-T$ path segments inferred from our results of $P-T$ modelling, while dashed curves show presumed portions of the paths. Deformation events $\left(D_{1}, D_{2}, D_{3}\right)$ and studied 
assemblages $\left(S, M_{1}, M_{2}, A, B_{1}, B_{2}, B_{3}\right)$ are shown along the $P-T$ paths.

\subsection{Model of the tectono-metamorphic evolution of the MGB}

754

755

The structutral-metamorphic data obtained during this study, along with previous works (e.g., Vearncombe, 1988a, 1988b; Jaguin et al., 2012) indicate that the different units of the MGB underwent a similar style of penetrative, left-lateral deformation, as well as deformation localisation along the boundaries between units with contrasted metamorphic evolutions (Fig 9). These features could be accounted for by a sequential evolution model as follows: During the early stage of the evolution of the MGB, shortening was accommodated by crustal thickening due to thrusts and/or transpressive shear zone activation, whereby the different units underwent prograde metamorphism upon burial at lower to midcrustal level, along moderate apparent geothermal gradients. At some point during the thickeningshortening process, the reverse component of the shear zones attenuated, as they evolved into a strike-slip regime. Shortening was no longer accommodated solely along the primary shear zones that localised deformation, but rather by a penetrative deformation distributed in the rocks of the MGB and surrounding terrains, and homogeneous, moderate crustal thickening, coincident with a metamorphic overprint along a high-T, low-P apparent geothermal gradient. Our results allow to suggest that the tectonic juxtaposition of the Murchison Unit and La France Formation took place following crustal thickening, after peak metamorphism and partial exhumation of the La France Formation, at which point the latter and a portion of the Murchison Unit underwent a similar metamorphic evolution. The greenschist-facies metamorphism of the Murchison Unit may have been locally overprinted by a slightly higher-grade metamorphism as a consequence of tectonic accretion. Similarly, the final juxtaposition of the Silwana Amphibolites to the rest of the belt occurred after peak metamorphism and exhumation, along a late-stage strike-slip shear zone.

\subsection{Implications for Archaean tectonic regimes}


778 It is generally assumed that a higher average geothermal gradient prevailed in Archaean lithospheres 779 relative to modern ones, thus maintaining weak lithospheres unable to withstand thickening (e.g. Rey and 780 Houseman, 2006). Furthermore, a hot, more buoyant sub-continental lithospheric mantle in the Archaean 781 (Griffin et al., 1998) would have inhibited lithosphere thickening by stacking in Archaean collisional 782 belts, as it would have enhanced gravitational potential energy build-up as relief formed. Therefore, in an 783 Archaean context, it is expected that convergence be accommodated by moderate thickening in its early 784 stage, but quickly volume forces would become dominant on boundary stresses as gravitational potential 785 energy builds up with increased thickening. Further thickening would be limited, and shortening would be 786 accommodated by lateral escape of material, leading to a steady state where lithospheric thickness remains constant as long as convergence goes on (Rey and Houseman, 2006). This shift between the dominance of boundary stress to volume forces would correspond to the transition from a tectonic regime dominated by oblique thrusting to one marked by strike-slip shearing. It has been recognised in the sequential evolution of a number of Archaean and Palaeoproterozoic orogens (e.g. Kusky and Polat, 1999, in the Superior province, Feybesse et al., 2006 in the Birimian of the West African Craton). On Archaean lithospheres, the threshold controlling this transition would be reached much earlier than in Phanerozoic orogens, thus aborting pronounced thickening.

The cold apparent geothermal gradients inferred for the La France Formation and Silwana Amphibolites of the Murchison Greenstone Belt are comparable to those encountered in collisional belts in Proterozoic and Phanerozoic orogens (Brown, 2009). Burial along low geothermal gradients to about $30 \mathrm{~km}$ implies that the lithosphere strength was sufficient to sustain substantial thickening and loading, at least for a period of time. Weakening of the crust could therefore not have occurred before burial of supracrustal sequences at mid-crustal depths. In fact, the $\mathrm{P}-\mathrm{T}$ paths followed by the La France Formation and the Silwana Amphibolites (Fig 9) inferred from our result are at odds with $\mathrm{P}-\mathrm{T}$ paths expected from metamorphic terrains in hot orogens (Chardon et al, 2009; Gapais et al, 2009). Indeed, $\mathrm{P}-\mathrm{T}$ paths 
803 followed by particles in hot orogens are reported to show cooling during decompression, a sign that 804 exhumation is slow enough to enable thermal reequilibration (e.g., P-T paths from the Limpopo Belt: Zeh 805 et al., 2004; Millonig et al., 2010). In contrast, the Silwana Amphibolites and La France Formation 806 underwent a relatively fast burial, as is indicated by steep prograde P-T vectors, followed, for the latter, 807 by a near-isothermal decompression. These features suggest that isotherms were not parallel to the surface 808 at the time of metamorphism, and consequently exhumation must have been driven by tectonic processes 809 rather than by homogeneous erosion. An intermediate model between typical Archaean and Phanerozoic 810 orogens, where crustal shortening is accommodated by moderate crustal thickening, by deformation 811 localisation along transpressive shear zones, as well as by strike-slip shearing and strain distribution at a 812 regional scale, would better account for the tectono-metamorphic features of the MGB (e.g. Cagnard et \&ิ 3 al., 2011).

The results of this study echo the metamorphic conditions reported in the south of the older, $3.5-3.2 \mathrm{Ga}$, Barberton Greenstone Belt (Dziggel et al., 2002 ; Diener et al., 2005 ; Moyen et al., 2006). The tectonometamorphic evolution of the BGB shows similar thermal and mechanical properties of the lithosphere of the Kaapvaal Craton before the formation of the MGB. It therefore seems likely that the Kaapvaal Craton was a rather cold craton compared to other Archaean provinces, thus illustrating certain variability in geodynamic processes within the Archaean.

\section{Conclusion}

The Murchison Greenstone Belt is a narrow volcano-sedimentary belt comprising various terrains that have been tectonically juxtaposed. The geological units that represent most of the belt underwent lowergreenschist to lower-amphibolite facies metamorphism along a relatively hot, $\sim 30^{\circ} \mathrm{C} / \mathrm{km}$ apparent geothermal gradient. Two small slivers, at the north-eastern and southern edges of the MGB respectively, were metamorphosed in the higher amphibolite facies. They underwent burial at more than $30 \mathrm{~km}$ deep 
along a relatively cold, $\sim 20^{\circ} \mathrm{C} / \mathrm{km}$ geotherm. The contact zones between the low-grade and high-grade

830 formations are narrow and sharp. They represent high-strain shear zones that account for major breaks in 831 metamorphic conditions across the belt. While deformation due to shortening is distributed at a regional 832 scale, we show that shortening was also accommodated by localisation of deformation along 833 transpressive, sinistral tectonic contacts accompanied by a top-to-the-south directed transport. This mode 834 of shortening accounted for the final juxtaposition of terrains that were metamorphosed at different 835 crustal levels in the MGB.

836 The evolution of orogenic belts during shortening, from a tectonic regime dominated by thrusting, 837 thickening, and deformation localisation coincident with prograde metamorphism, to one dominated by 838 strike-slip shearing, lateral flow and deformation distribution accompanied by retrograde metamorphic overprints, is not specific of or restricted to any time period in the geological record. As shown by our results and by studies of the Barberton Greenstone Belt, moderate thickening, high-P, moderate- to low-T metamorphism and high metamorphic gradients do occur in the Archaean. However, secular changes in the heat budget of the Earth must have affected the relative importance of the different modes of shortening, and probably account for the clearly contrasting tectonic features between the Archaean and Proterozoic eras. In any case, drawing geodynamic models illustrating the differential behaviour of Archaean and Proterozoic orogens should not be done without a consideration for the possible variations of the parameters determining the rheological profiles and, as a consequence, the behaviour of 847 lithospheres at a given age.

Appendix

\section{A.1. XRF and microprobe analysis}

Whole rock chemistry analyses were obtained using an ACME at University of Stellenbosch, South Africa. Complementary analyses were obtained by XRF at the CRPG in Nancy and the at the Ecole des 
855 Mines in Saint-Etienne. Mineral chemical analyses were performed on a LEO 140VP scanning electron 856 microscope coupled to a Link ISIS energy dispersive spectrometry system at the University of 857 Stellenbosch. The microscope was operated at $20 \mathrm{kV}$ with a beam current of $120 \mathrm{~A}$ and a probe current of $8581.5 \mathrm{nA}$. Acquisition time was set at $50 \mathrm{~s}$ and spectra were processed by ZAF corrections and quantified 859 using natural mineral standards. Details of the analytical procedure are provided in Diener et al. (2005). 860 Complementary analyses were carried out at the Electron Microprobe Laboratory at Université Blaise 861 Pascal in Clermont-Ferrand, France, using a Cameca SX 100 electron microprobe analyser. Operating 862 conditions were $20 \mathrm{kV}, 20 \mathrm{nA}, 5-10 \mu \mathrm{m}$ beam size and counting time of 10 s per element. Natural silicates 863 were used as standards. The analyses carried out in the different laboratories were identical within errors.

\section{A.2. Pseudosection calculation}

Pseudosections of rocks from the different terrains of the MGB were constructed using the Peple_X software (Connolly and Kerrick, 1987; Connolly, 2005; 2009) in the $\mathrm{Na}_{2} \mathrm{O}-\mathrm{CaO}-\mathrm{K}_{2} \mathrm{O}-\mathrm{FeO}-$ $\left(\mathrm{Fe}_{2} \mathrm{O}_{3}-\right) \mathrm{MgO}-\mathrm{MnO}-\mathrm{Al}_{2} \mathrm{O}_{3}-\mathrm{TiO}_{2}-\mathrm{SiO}_{2}-\mathrm{H}_{2} \mathrm{O}$ system, and using the thermodynamic database hp04 of Holland and Powell (1998, revised 2004). The solution models used for the pseudosections are as follows : Bio(TCC) for biotite (Tajcmanova et al., 2009), Chl(HP) for chlorite (Holland et al., 1998), St(HP) for staurolite (Powell et al., 1998), Ctd(HP) for chloritoïd (Holland and Powell), Amph(DPW) for amphibole 873 (Dale et al., 2005), Gt(WPH) for garnet (White et al., 2000), Ilm(WPH) for ilmenite (White et al., 2000), 874 hCrd for cordierite, Mica(CHA1) for titanium bearing white mica (Coggon and Holland, 2002, Auzanneau et al., 2010), Pheng(HP) for phengite (Holland and Powell 1998), melt(HP) (Holland and Powell, 2001), Pl(h) for plagioclase feldspar (Newton et al. 1981), Kf for potassic feldspar (Waldbaum and Thompson 1968), Opx(HP) for orthopyroxene (Holland and Powell, 1996), Cpx (HP) for 878 clinopyroxene (Holland and Powell, 1996). Pseudosections were first built by using the bulk rock 879 composition obtained by XRF analysis of each sample. However, this method failed to model accurately 880 the observed assemblages and mineral compositions for samples bearing large, centimetric minerals. For 
881 such samples, the bulk rock composition was calculated from the mineral modes and average mineral 882 compositions (e.g. samples A, B and S, Table 4). Modal proportions were estimated by image analysis, 883 and average mineral compositions were obtained by averaging a large number of microprobe analyses 884 acquired on minerals of a single thin section. In order to show the effect of garnet fractionation on the $\mathrm{P}$ 885 T pseudosection topology (e.g., sample A), we obtained the total bulk compositions by XRF, as well as 886 the effective bulk composition after porphyroblast garnet growth, by subtracting the core composition of 887 the zoned garnet grains (ca. 10 vol.\%) from the total bulk composition, using a method similar to the 888 procedure described by Marmo et al. (2002) and Zeh et al. (2006).

889

\begin{tabular}{|c|c|c|c|c|c|c|c|c|c|c|}
\hline \multicolumn{6}{|c|}{$\begin{array}{l}\text { Whole rock XRF (wt\%) - all Fe as } \\
\sqrt{{ }_{F} e^{2+}}\end{array}$} & \multicolumn{5}{|c|}{ Recalculated (wt\%) } \\
\hline S & $\mathrm{A}$ & B & M1 & M2 & $S$ & & $\begin{array}{l}\text { A with Gt } \\
\text { cores }\end{array}$ & $\begin{array}{l}\text { A without } \\
\text { Gt cores }\end{array}$ & B & $S$ \\
\hline 气्व: $\mathrm{SiO}_{2}$ & 75.62 & 56.51 & 62.55 & 92.99 & 55.68 & $\mathrm{SiO}_{2}$ & 61.67 & 64.24 & 47.00 & 52.41 \\
\hline $\mathrm{Al}_{2} \mathrm{O}_{3}$ & 11.76 & 17.39 & 6.96 & 2.84 & 12.09 & $\mathrm{Al}_{2} \mathrm{O}_{3}$ & 15.30 & 14.73 & 23.75 & 12.61 \\
\hline $\mathrm{N}_{\mathrm{FeO}}$ & 6.68 & 8.08 & 7.13 & 1.77 & 16.21 & $\mathrm{FeO}$ & 14.97 & 12.87 & 9.54 & 22.01 \\
\hline -MnO & 0.04 & 0.07 & 0.14 & 0.10 & 0.18 & MnO & 0.51 & 0.19 & 0.00 & 0.52 \\
\hline 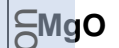 & 1.52 & 8.45 & 12.32 & 0.54 & 2.77 & $\mathrm{MgO}$ & 1.73 & 1.75 & 8.44 & 2.64 \\
\hline ज़CaO & < D.L. & 0.52 & 5.58 & 0.07 & 7.19 & $\mathrm{CaO}$ & 0.46 & 0.27 & 0.30 & 6.08 \\
\hline$\overline{\mathrm{Na}}_{2} \mathrm{O}$ & 0.17 & 0.61 & 1.27 & 0.00 & 2.89 & $\mathrm{Na}_{2} \mathrm{O}$ & 0.12 & 0.13 & 0.50 & 1.16 \\
\hline$\Omega^{-K_{2}} \mathrm{O}$ & 2.64 & 4.87 & 0.02 & 0.58 & 0.24 & $\mathrm{~K}_{2} \mathrm{O}$ & 1.92 & 2.12 & 6.41 & 0.29 \\
\hline $\mathrm{TiO}_{2}$ & 0.20 & 0.58 & 0.30 & 0.10 & 2.04 & $\mathrm{TiO}_{2}$ & 0.19 & 0.21 & 0.63 & 0.84 \\
\hline${ }_{6} \mathrm{P}_{2} \mathrm{O}_{5}$ & 0.17 & b.d.l. & 0.02 & 0.00 & 0.81 & $\mathrm{H}_{2} \mathrm{O}$ & 1.50 & 1.50 & sat. & sat. \\
\hline อ LOI & 2.35 & 2.99 & 3.40 & 1.06 & 0.89 & $\mathrm{Fe}_{2} \mathrm{O}_{3}$ & 0.00 & 0.00 & 0.00 & 0.00 \\
\hline Total & 101.15 & 100.07 & 99.69 & 100.05 & 100.99 & Total & 98.37 & 98.01 & 96.57 & 98.56 \\
\hline
\end{tabular}

892 Table 4:

893 Whole rock compositions of the studied samples. The pseudosections of samples from the Murchison Unit 894 (M1 and M2) were built using the whole rock compositions obtained by XRF analysis. Whole rock 895 compositions were recalculated for the other samples to take into account the effect of large 896 porphyroblasts on the composition of an equilibration volume (samples $A, B$ and $S$ ) or to correct the effect 897 of accessory phases (sample S, see appendix A2).

$899 \mathrm{Fe}_{2} \mathrm{O}_{3}$ of the bulk rock was estimated by calculating the $\mathrm{Fe}^{3+}$ content of normalised structural formulae of 900 analysed minerals (Droop, 1987) and from mineral modes. By applying this procedure we obtained $\mathrm{Fe}_{2} \mathrm{O}_{3}$ 901 contents of less than $0.05 \mathrm{wt} \%$ for all samples. $\mathrm{T}-\mathrm{X}$ pseudosections were constructed to test the 
902 implications of approximating all $\mathrm{Fe}$ as $\mathrm{Fe}^{2+}$. In all cases, the consequences in terms of phase 903 compositions and proportions were found to be negligible. Thus, $\mathrm{Fe}_{2} \mathrm{O}_{3}$ as a system component was 904 ignored during this study, since it is little influential. Other corrections included correcting whole rock Ca 905 content for apatite and calcite in the studied sample, using calcite modal proportions and bulk $\mathrm{P}_{2} \mathrm{O}_{5}$ 906 composition. As a general rule, oxydes with a bulk rock content $<0.05$ wt $\%$ were ignored for 907 pseudosection calculations.

908 The prograde history of fluid-bearing mineral assemblages involves the progressive dehydration and fluid 909 loss with rising temperature. The water content of a rock decreases along the prograde path and reaches a 910 minimum at peak metamorphic conditions. Unless a secondary water enrichment occurs (such as 211 documented in sample B), the water content along the retrograde path is assumed to be close to the water content at peak $\mathrm{T}$ conditions. As the retrograde assemblages of the investigated samples require a postpeak metamorphism water influx, the $\mathrm{P}-\mathrm{T}$ pseudosections for all samples were constructed under the assumption that water was in excess throughout the entire metamorphic history.

\section{A.3. LA-ICP-MS U-Th-Pb dating}

A classic mineral separation procedure has been applied to concentrate zircon grains using the facilities available at Géosciences Rennes. Rocks were crushed and only the powder fraction with a diameter $<250$ $\mu \mathrm{m}$ was kept. Heavy minerals were successively concentrated by Wilfley table and heavy liquids. Magnetic minerals were then removed with an isodynamic Frantz separator. Zircon grains were handpicked under a binocular microscope and embedded in epoxy mounts. The grains were then handgrounded and polished on a lap wheel with a $6 \mu \mathrm{m}$ and $1 \mu \mathrm{m}$ diamond suspension successively. Zircons were imaged by cathodoluminescence (CL) using a Reliotron CL system equipped with a digital color 924 camera available in Géosciences Rennes.

U-Th- $\mathrm{Pb}$ geochronology of zircon from the sample mur0982 was conducted by in-situ laser ablation inductively coupled plasma mass spectrometry (LA-ICPMS) at the Laboratoire Magmas et 
928 Volcans in Clermont-Ferrand, France, using a Resonetics M-50E 193 nm ArF excimer NewWave UP213 929 laser system, with a laser spot diameter of $26 \mu \mathrm{m}$ and repetition rates of $3 \mathrm{~Hz}$. Data were corrected for U$930 \mathrm{~Pb}$ fractionation and for the mass bias by standard bracketing with repeated measurements of the GJ-1 931 zircon (Jackson et al., 2004). Data reduction was carried out with the GLITTER® software package 932 developed by the Macquarie Research Ltd. (Jackson et al., 2004). Further information on the 933 instrumentation and the analytical technique is detailed in Hurai et al. (2010).

$\mathrm{U}-\mathrm{Pb}$ dating of monazite and xenotime was carried out on polished thin sections at Goethe 936 University Frankfurt, Germany. Prior to the U-Pb dating, the internal structures of the grains were 937 investigated by back-scattered electron (BSE) imaging using a ThermoScientific Element 2 sector field ICP-MS coupled to a Resolution M-50 (Resonetics) $193 \mathrm{~nm}$ ArF excimer laser (ComPexPro 102F, Coherent) system. Data were acquired in time resolved - peak jumping - pulse counting / analogue mode over 356 mass scans, with a 20 second background measurement followed by 21 second sample ablation. Laser spot-size for monazite and xenotime are $15 \mu \mathrm{m}$, and $23 \mu \mathrm{m}$ for the standard zircons GJ1. Ablations were performed in a $0.6 \mathrm{~L} \mathrm{~min}^{-1} \mathrm{He}$ stream, which was mixed directly after the ablation cell with $0.07 \mathrm{~L}$ $\min ^{-1} \mathrm{~N}_{2}$ and $0.68 \mathrm{~L} \mathrm{~min}^{-1}$ Ar prior to introduction into the Ar plasma of the SF-ICP-MS. All gases had a purity of $>99.999 \%$ and no homogeniser was used while mixing the gases to prevent smoothing of the signal. Signal was tuned for maximum sensitivity for $\mathrm{Pb}$ and $\mathrm{U}$ while keeping oxide production, monitored as ${ }^{254} \mathrm{UO} /{ }^{238} \mathrm{U}$, below $0.5 \%$. The sensitivity achieved was in the range of $9000-14000 \mathrm{cps} / \mu \mathrm{g} \mathrm{g}$ $947{ }^{1}$ for ${ }^{238} \mathrm{U}$ with a $23 \mu \mathrm{m}$ spot size, at $5.5 \mathrm{~Hz}$ and $5-6 \mathrm{~J} \mathrm{~cm}^{-2}$ laser energy. The two-volume ablation cell 948 (Laurin Technic, Australia) of the M50 enables detection and sequential sampling of heterogeneous 949 grains (e.g., growth zones) during time resolved data acquisition, due to its quick response time of $<1$ s 950 (time until maximum signal strength was achieved) and wash-out ( $<99.9 \%$ of previous signal) time of 951 about $2 \mathrm{~s}$. With a depth penetration of $\sim 0.7 \mu \mathrm{ms}^{-1}$ and a $0.46 \mathrm{~s}$ integration time ( 4 mass scans $=0.46 \mathrm{~s}=1$ 952 integration) any significant variation of the $\mathrm{Pb} / \mathrm{Pb}$ and $\mathrm{U} / \mathrm{Pb}$ in the $\mu \mathrm{m}$ scale is detectable. Raw data were 953 corrected offline for background signal, common $\mathrm{Pb}$, laser induced elemental fractionation, instrumental 
954 mass discrimination, and time-dependent elemental fractionation of $\mathrm{Pb} / \mathrm{U}$ using an in-house MS Excel ${ }^{\circledR}$ 955 spreadsheet program (Gerdes and Zeh, 2006; 2009). A common-Pb correction based on the interference956 and background-corrected ${ }^{204} \mathrm{~Pb}$ signal and a model $\mathrm{Pb}$ composition (Stacey \& Kramers 1975) was carried 957 out. The ${ }^{204} \mathrm{~Pb}$ content for each ratio was estimated by subtracting the average mass 204 signal, obtained 958 during the 20 second baseline acquisition, which mostly results from ${ }^{204} \mathrm{Hg}$ in the carrier gas (c. $180-420$ 959 cps), from the mass 204 signal of the respective ratio. For the analyzed sample the calculated common $960{ }^{206} \mathrm{~Pb}$ contents was mostly $<1 \%$ of the total ${ }^{206} \mathrm{~Pb}$ (see Table 3). For more details about data processing see 961 (Gerdes and Zeh, 2006; 2009). The data were plotted using the software ISOPLOT (Ludwig 2001).

962

\section{Acknowledgements}

The authors thank Michael Brown for his detailed review of the manuscript which contributed to improve significantly the quality of the work. Timothy Kusky and an anonymous reviewer are also thanked for their constructive comments. The participation of Arnaud Villaros through discussions and advice was greatly appreciated. Preliminary results of this study were presented at the $5^{\text {th }}$ International Archaean Symposium in Perth in 2010 thanks to a travel grant provided by Geoconferences (WA) Inc. Armin Zeh also thanks the Deutsche Forschungsgemeinschaft, grant ZE 424/11-1, for financial support.

\section{References}

Altermann, W. and Nelson, D.R.., 1998. Sedimentation rates, basin analysis and regional correlations of three Neoarchaean and Palaeoproterozoic sub-basins of the Kaapvaal Craton, Northern Cape Province, South Africa. J. Afr. Earth Sci., 13, 415-435.

Anhaeusser, C.R., 2006. A reevaluation of Archean intracratonic terrane boundaries on the Kaapvaal Craton, South Africa: Collisional suture zones? GSA Special Papers 2006, 405 193-210 
981 Auzanneau, E., Schmidt, M.W., Vielzeuf, D., Connolly, J.A.D., 2010. Titanium in phengite: a geobarometer for high temperature eclogites. Contrib. Mineral. Petrol. 159, 1-24.

Berthé, D., Choukroune, P., Jegouzo, P., 1979. Orthogneiss, mylonite and non-coaxial deformation of granites : the example of the South Armorican shear zone. J. Struct. Geol. 1, 31-43.

Binns, R.A., Gunthrope, R.J. and Groves, D.I., 1976. Metamorphic patterns and development of

Bouhallier, H., Chardon, D., Choukroune, P., 1995. Strain patterns in Archaean dome-and-basin greenstone belts in the eastern Yilgarn Block, Western Australia. In: Windley, B.F. (ed.). The Early History of the Earth. Wiley, New York, N.Y., 303-316.

Bouhallier, H., Choukroune, P. and Ballevre, M., 1993. Diapirism, bulk homogenous shortening and transcurrent shearing in the Archaean Dharwar craton: the Holenarsipur area. Precambrian Res., 63, 43-58. structures: the Dharwar craton (Karnataka, South India). Earth Planet. Sci. Lett. 135, 57-75.

Brandl, G., Kröner, A., 1993. Preliminary results of single zircon studies from various Archaean rocks of the Northeastern Transvaal. In: Ext. Abstr. 16th International Colloquium of African Geology, Mbabane, Swaziland, 54-56.

Brandl, G., Jaeckel, P., Kröner, A., 1996. Single zircon age for the felsic Rubbervale Formation, Murchison greenstone belt, South Africa. S. Afr. J. Geol. 99, 3, 229-234.

Brandl, G., Cloete, M., Anhaeusser, C.R., 2006. Archaean Greenstone Belts, In: Johnson, M.R., 
Anhaeusser, C.R., Thomas, R.J., The Geology of South Africa, 2006.

Brown, M., 2007. Metamorphic conditions in orogenic belts: a record of secular change. Int. Geol. Rev. 49:193-234

Publ., 37-74

Brown, M., 2009. Metamorphic patterns in orogenic systems and the geological record. In: Cawood PA, Kroner A (eds) Earth accretionary systems in space and time, vol 318. Geol. Soc. Lond. Spec.

Brown, M., 2010. Paired metamorphic belts revisited. Gondwana Research 18, 46-59.

Burger, A.J., Coertze, F.J., 1973. Radiometric age measurements on rocks from southern Africa to the end of 1971. Bull. Geol. Surv. S. Afr. 58, 46-46.

Caby, R., Delor, C., Agoh, O., 2000. Lithologie, structure et métamorphisme des formations birimiennes dans la région d'Odienné (Côte d'Ivoire): rôle majeur du diapirisme des plutons $\quad$ et des décrochements en bordure du craton de Man. J. Afr. Earth Sci. 30, 351-374.

Cagnard, F., Barbey, P., Gapais, D., 2011. Transition between "Archaean-type" and "modern-type" tectonics : Insights from the Finnish Lapland Granulite Belt. Precambrian Res. 187, 127-142.

Cawood, P., Kröner, A., Collins, W.J. et al., 2009. Accretionary orogens through Earth histoiry. Geol. Soc. Lond. Spec. Publ., 318, 1-36.

Chardon, D., Choukroune, P., Jayananda, M., 1996. Strain patterns, décollement and incipient sagducted greenstone terrains in the Archaean Dharwar craton (South India). J. Struct. Geol. 18, 991-1004. 
1033 Chardon, D., Choukroune, P., Jayananda, M., 1998. Sinking of the Dharwar basin (South India): implications for Archaean tectonics. Precambrian Res. 91, 15-39.

1035

Chardon, D., Andronicos, C.L., Hollister, L.S., 1999. Large-scale transpressive shear zone patterns and displacements within magmatic arcs: the Coast Plutonic Complex, British Columbia. Tectonics 18, 278-292.

Chardon, D., Jayananda, M., Chetty, T.R.K., Peucat, J.-J., 2008. Precambrian continental strain and shear zone patterns: South Indian case. J. Geophys. Res. 113, B08402, doi:10.1029/2007JB005299.

Chardon, D., Gapais, D., Cagnard, F., 2009. Flow of ultra-hot orogens: a view from Precambrian, clues for the Phanerozoic. Tectonophysics 477 (3-4), 105-118.

Chopin, C., 1984. Coesite and pure pyrope in high-grade blueschists of the western Alps: a first record and some consequences. Contrib. Mineral. Petrol. 86, 107-118.

Choukroune, P., Bouhallier, H., Arndt, N.T., 1995. Soft lithosphere during periods of Archean crustal growth or crustal reworking. In: Coward, M.P., Ries, A.C. (Eds.), Early Precambrian Processes. Geol. Soc. Spec. Publ., 95, 67-86.

Choukroune, P., Ludden, J.N., Chardon, D., Calvert, A.J., Bouhallier, H., 1997. Archaean crustal growth and tectonic processes: a comparison of the Superior Province, Canada and the Dharwar craton, India. In: Burg, J.-P., Ford, M. (Eds.), Orogeny through Time. Geol. Soc. Spec. Publ., 121, 63-98. 
Coggon, R., Holland, T.J.B., 2002. Mixing properties of phengitic micas and revised garnet-phengite thermobarometers. J. Metamorph. Geol. 20, 683-96.

Collins, W.J., Vernon, R.H., 1991. Orogeny associated with anticlockwise P-T-t paths: evidence from low-P, high-T metamorphic terranes in the Arunta inlier, central Australia. Geology 19, 835-838.

Compston, W., Kröner, A., 1988. Multiple zircon growth within early Archean tonalitic gneiss from the Ancient Gneiss Complex, Swaziland. Earth Planet. Sci. Lett. 87, 13-28.

Connolly, J. A. D., 2005. Computation of phase equilibria by linear programming : A tool for geodynamic modeling and its application to subduction zone decarbonation. Earth Planet. Sci. Lett. 236, 524541.

Connolly, J. A. D., 2009. The geodynamic equation of state : what and how. Geochemistry, Geophysics, Geosystems 10.

Connolly, J. A. D. and Kerrick, D.M., 1987. An algorithm and computer program for calculating composition phase diagrams. CALPHAD 11:1-

Condie, K. C. and Kröner, A., 2008. When did plate tectonics begin? Evidence from the geologic record in Condie, K. C. and Pease, V. eds. When Did Plate Tectonics Begin on Planet Earth? Geological Society of America Special Paper 440, 281-294, doi: 10.1130/2008.2440(14).

Dale, J., Powell, R., White, R.W., Elmer, F.L., Holland, T.J.B., 2005. A thermodynamic model for Ca-Na clinoamphiboles in Na2O-CaO-FeO-MgO-Al2O3-SiO2-H2O-O for petrological calculations. J. Metamorph. Geol. 23, 771-91. 
Diener, J.F.A, Stevens, G., Kisters, A.F.M, Poujol, M., 2005. Metamorphism and exhumation of the basal parts of the Barberton greenstone belt, South Africa: Constraining the rates of Mesoarchaean tectonism. Precambrian Res.143, 87-112.

Diener, J.F.A., Powell, R., 2010. Influence of ferric iron on the stability of mineral assemblages. J. Metamorph. Geol., 28, 599-613.

De Wit, M., 2004. Archean greenstone belts do contain fragments of ophiolites. In Condie, K. C., Kusky, T. M. (Editors), Precambrian Ophiolites and Related Rocks, Developments in Precambrian Geology v. 13, Elsevier Publishers.

Droop, G.T.R., 1987. A general equation for estimating $\mathrm{Fe}^{3+}$ concentrations in ferromagnesian silicates and oxides from microprobe analyses, using stoichiometric criteria. Mineralogical Magazine, 51 ( 3), 361, 431-435.

Du Plessis, C. P., 1990. Tectonism along the Thabazimby-Murchison lineament. Ph.D. Thesis (unpubl.), Univ Witwatersrand, Johannesburg, 243 pp.

Dziggel, A., Stevens, G., Poujol, M., Anhaeusser, C.R., Armstrong, R.A., 2002. Metamorphism of the granite-greenstone terrane south of the Barberton greenstone belt, South Africa: an insight into the tectono-thermal evolution of the 'lower' portions of the Onverwacht Group. 
Precambrian Res. 114, 221-247.

England, P. C. and Thompson, A. B., 1984. Pressure - temperature - time paths of regional metamorphism, Part I; heat transfer during the evolution of regions of thickened continental crust. J. Petrol., 25, 894-928.

Ernst, W.G., 1975. Systematics of large-scale tectonics and age progressions in Alpine and circumPacific blueschist belts. Tectonophysics 26, 229-246.

Ernst, W.G., 1988. Tectonic history of subduction zones inferred from retrograde blueschist $\mathrm{P}-\mathrm{T}$ paths. Geology 16, 1081-1084.

Evans, T. P., 2004. A method for calculating effective bulk composition modification due to crystal fractionation in garnet bearing schist: implications for isopleth thermobarometry. J. Metamorph. Geol. 22, 547-557.

Feybesse, J.-L., Billa, M., Guerrit, C., Duguey, E., Lescuyer, J.-L., Milesi, J.P., Bouchot, V., 2006. The paleoproterozoic Ghanaian province : Geodynamic model and ore controls, including regional stress modeling. Precambrian Res. 149, 149-196.

Florence, F. P. and Spear, F. S., 1991. Effects of diffusional modification of garnet growth zoning on P-T path calculations. Contrib. Mineral. Petrol., 107, 487-500. 
Gapais, D., Cagnard, F., Gueydan, F., Barbey, P., Ballèvre, M., 2009. Mountain building and exhumation processes through time: inferences from nature and models. Terra Nova 21, 188-194.

Gerdes, A. and Zeh, A., 2006. Combined U-Pb and Hf isotope LA-(MC)ICP-MS analyses of detrital zircons: Comparison with SHRIMP and new constraints for the provenance and age of an Armorican metasediment in Central Germany. Earth and Pl. Sci. Letters 249, 47-61.

Good, N. and M.J. De Wit, 1997. The Thabazimbi-Murchison Lineament of the Kaapvaal craton, South Africa : 2700 Ma of episodic deformation. Journal of the Geological Society 154, 1, 93-97.

Grambling, J.A., 1986. Crustal thickening during Proterozoic metamorphism and deformation in New Mexico. Geology 14, 149-152.

Griffin, W.L., O'Reilly, S.Y., Ryan, C.G., Gaul, O., Ionov, D., 1998. Secular variation in the composition of the subcontinental lithospheric mantle. In: Braun, J. et al. (eds). Structure and Evolution of the Australian Continent, Geodynamics Series, 26, American Geophysical Union, 1-25.

Henderson, D.R., Long, L.E. and Barton, J.M., 2000. Isotopic ages and chemical and isotopic compositions of the Archaean Turfloop Batholith, Pietersburg granite-greenstone terrane, Kaapvaal

1159 Craton, South Africa. S. Afr. J. Geol., 103(1): 38-46. 
Hurai, V., Paquette, J.-L., Huraiová, M., Konečný, P., 2010. U-Th-Pb geochronology of zircon and monazite from syenite and pincinite xenoliths in Pliocene alkali basalts of the intraCarpathian back-arc basin. J. Volcanol. Geotherm. Res., 198, 275-287.

Holland, T., Powell, R., 1996. Thermodynamics of order-disorder in minerals. 2. Symmetric formalism applied to solid solutions. Am. Min. 81, 1425-37.

Holland, T.J.B. and Powell, R., 1998. An internally consistent thermodynamic data set for phases of petrological interest. J. Metamorph. Geol. 16, 309-43

Holland, T., Baker, J., Powell, R. 1998. Mixing properties and activity-composition relationships of chlorites in the system $\mathrm{MgO}-\mathrm{FeO}-\mathrm{Al}_{2} \mathrm{O}_{3}-\mathrm{SiO}_{2}-\mathrm{H}_{2} \mathrm{O}$. European Journal of Mineralogy $\quad \mathbf{1 0}, \quad 395$ 406.

Holland, T., Powell, R., 2001. Calculation of phase relations involving haplogranitic melts using an internally consistent thermodynamic dataset. J. Petrol. 42, 673-83.

Jaguin, J., Gapais, D., Poujol, M. , Boulvais, P. et Moyen, J.F. (in press). The Murchison Greenstone Belt (South Africa) : a general tectonic framework. S.Afr.J.Geol., 115, 1, 65-76.

Jackson, S.E., Pearson, N.J., Griffin, W.L., Belousova, E.A., 2004. The application of laser ablationinductively coupled plasma-mass spectrometry to in situ U-Pb zircon geochronology. Chem. Geol., 211, 47-69.

Kamo, S.L., Davis, D.W., 1994. Reassessment of Archaean crustal development in the Barberton Moutain Land, South Africa, based on U-Pb dating. Tectonics 13 (1), 167-192. 
1188 Kisters, A.F.M., Stevens, G., Dziggel, A., Armstrong, R.A., 2003. Extensional detachment faulting and core-complex formation in the southern Barberton granite-greenstone terrain, South Africa: evidence for a 3.2 Ga orogenic collapse. Precambrian Res. 127, 355-378.

Komiya, T., Maruyama, S., Masuda, T., Nobda, S., Hayashi, M. \& Okamoto, K. 1999. Plate tectonics at

3.8-3.7 Ga: Field evidence from the Isua Accretionary Complex, southern West Greenland. Journal of Geology, 107, 515-554.

Komiya, T., Hayashi, M., Maruyama, S. and Yurimoto, H., 2002. Intermediate-P/T type Archaean metamorphism of the Isua supracrustal belt: Implications for secular change of geothermal gradients at subduction zones and for Archaean plate tectonics. American Journal of Science, 302, 806-826.

Kröner, A., Byerly, G.R., Lowe, D.R., 1991. Chronology of early Archean granite-greenstone evolution in the Barberton Moutain Land, South Africa, based on precise dating by single grain zircon evaporation. Earth Planet. Sci. Lett. 103, 41-54.

Kröner, A., Hegner, E., Byerly, G.R., Lowe, D.R., 1992. Possible terrane identification in the early Archaean Barberton greenstone belt, South Africa, using single zircon geochronology. EOS Trans. AGU, Fall Meeting Suppl. 73 (43), 616.

Kröner, A., Tegtmeyer, A., 1994. Gneiss-greenstone relationships in the Ancient Gneiss Complex of southwestern Swaziland, southern Africa, and implications for early crustal evolution. Precambrian Res. 67, 109-139.

Kröner, A., Hegner, E., Wendt, J.I., Byerly, G.R., 1996. The oldest part of the Barberton granitoid- 
Kröner, A., Jaeckel, P., Brandl, G., 2000. Single zircon ages for felsic to intermediate rocks from the Pietersburg and Giyani greenstone belts and bordering granitoid orthogneisses, northern Kaapvaal Craton, South Africa. J. Afr. Earth Sci. 30 (4), 773- 793.

Kusky, T. M., 1991. Structural development of an Archean orogen, western Point Lake, Northwest Territories. Tectonics, 10, 4, p. 820-841.

Kusky, T.M., Vearncombe, J.R., 1997. Structural aspects. In: de Wit, M., Ashwal, L.D. (Eds.), Greenstone Belts. Oxford Monogr. Geol. Geophys. 35, 91-124.

Kusky, T. M. and Polat, A. 1999. Growth of granite-greenstone terranes at convergent margins, and stabilization of Archean cratons. Tectonophysics 305, 43-73

Kusky, T.M., Li, Jianghai, and Tucker, R.T., 2001. The Archean Dongwanzi ophiolite complex, North China Craton: 2.505 Billion Year Old Oceanic Crust and Mantle, Science, 292, 1142-1145.

Ludwig, K.R., 1998. On the Treatment of Concordant Uranium-Lead Ages. GeCA, 62, 4, 665-676.

Ludwig, K.R., 2001. Isoplot/Ex, rev. 2.49: a geochronological toolkit for Microsoft Excel. Berkeley

Geochronology Center, Spec. Publ. 1a, 55 p.

Marmo, B.A., Clarke, G.L., Powell, R., 2002. Fractionation of bulk rock composition due to porphyroblast growth : effects on eclogite facies mineral equilibria, Pam Peninsula, New 
Millonig, L., Zeh, A., Gerdes, A. \& Klemd, R. (2008). Neoarchaean high-grade metamorphism in the Central Zone of the Limpopo Belt (South Africa): Combined petrological and geochronological evidence from the Bulai pluton. Lithos, 103, 333-351.

Millonig, L., Zeh, A., Gerdes, A., Klemd, R., Barton, J.M., 2010. Decompressional Heating of the Mahalapye Complex (Limpopo Belt, Botswana): a Response to Palaeoproterozoic Magmatic Underplating ? J. Petrol. 51, 3, 703-729.

Mints, M. V., Belousova, E. A., Konilov, A. N., Natapov, L. N., Shchipansky, A. A., Griffin, W. L., O'Reilly, S. Y., Dokukina, K. A., Kaulina, T. V., 2010. Mesoarchean subduction processes: $2.87 \mathrm{Ga}$ eclogites from the Kola Peninsula, Russia. Geology 38, 739-742.

Miyashiro, A., 1961. Evolution of metamorphic belts. J. Petrol. 2, 277-311.

Moyen, J.F., Stevens, G., Kisters, A., 2006. Record of mid-Archean subduction from metamorphism in Barberton Terrain, South Africa. Nature 442, 559-562

Newton, R.C., Charlu, T.V., ,Kleppa, O.J., 1980. Thermochemistry of the high structural state plagioclases. GeCA 44, 933-41.

Park, R.G., 1982. Archaean tectonics. Geol. Rundsch. 71, 22-37.

Percival, J.A., Fountain, D.M., Salisbury, M.H., 1992. Exposed crustal cross sections as windows on the 
1265 lower crust. In: Fountain, D.M., Arculus, R.J., Kay, R.W. (Eds.), Continental Lower Crust. Elsevier, 1266 Amsterdam, 317-362.

Percival, J., 1994. Archean high-grade metamorphism. In: Condie, K.C. (Ed.), Archean crustal evolution.

Developments in Precambrian Geology 1 1, Elsevier, 357-410..

Platt, J.P, and Visser, R.L.M., 1980. Extensional structures in anisotropic rocks. J. Struct. Geol. 2, 397410.

Poujol, M., Robb, L.J., Respaut, J.P., Anhaeusser, C.R., 1996. 3.07-2.97 Ga greenstone belt formation in the northeastern Kaapvaal Craton: implications for the origin of the Witwatersrand Basin. Econ. Geol. 91 (8), 1455-1461.

Poujol, M., Respaut, J.P., Robb, L.J. and Anhaeusser, C.R., 1997. New U-Pb and Pb-Pb data on the Murchison greenstone belt, South Africa and their implications for the origin of the Witwatersrand basin. 319, EGRU, Johannesburg.

Poujol, M. and Robb, L.J., 1999. New U-Pb zircon ages on gneisses and pegmatite from South of the Murchison greenstone belt, South Africa. S. Afr. J. Geol., 102(2): 93- 97.

Poujol, M., 2001. U-Pb isotopic evidence for episodic granitoid emplacement in the Murchison greenstone belt, South Africa. J. Afr. Earth Sci. 33, 155-163.

Powell R., Holland T. J. B. and Worley B., 1998. Calculating phase diagrams involving solid solutions via non-linear equations, with examples using THERMOCALC. J. Metamorph. Geol. 16, 577-588. 
Reno, B.L., Brown, M., Kobayashi, O.T., Nakamura, E., Piccoli, P.M. and Trouw, R.A.J., 2009.

Eclogite-high-pressure granulite metamorphism records early collision in West Gondwana: New data from the Southern Brasília Belt, Brazil. J. Geol. Soc. Lond, 166, 1013-1032.

Rey, P.F., and Houseman, G., 2006. Lithospheric scale gravitational flow: the impact of body forces on orogenic processes from Archaean to Phanerozoic, In: Buiter, S. J. H. and Schreurs, G.(eds). Analogue and Numerical Modelling of Crustal Scale Processes. Geol. Soc. Lond. Spec. Publ., 253, 153-167.

Robb, L.J., Brandl, G., Anhaeusser, C.R., Poujol, M., 2006. Archaean Granitoid Intrusions, In: Johnson, M.R., Anhaeusser, C.R., Thomas, R.J., The Geology of South Africa, 2006.

Saha, L., Pant, N.C., Pati, J.K., Upadhyay, D., Berndt, J., Bhattacharya, A., Satynarayanan, M., 2011.

Neoarchean high-pressure margarite-phengitic muscovite-chlorite corona mantled corundum in quartz-free high-Mg, Al phlogopite-chlorite schists from the Bundelkhand craton, north central India. Contrib. Mineral. Petrol. 161, 511-530.

Schwartz-Schampera, U., Terblanche, H., Oberthür, T., 2010. Volcanic-hosted massive sulfide deposits in the Murchison greenstone belt, South Africa. Mineralium Deposita 45, 2, 113-145.

Sizova, E., Gerya, T., Brown, M., Perchuk, L.L., 2010. Subduction styles in the Precambrian: insight from numerical experiments. Lithos 116, 3-4, 209-22.

Smith, D.C., 1984. Coesite in clinopyroxene in the Caledonides and its implications for geodynamics.

\section{Nature 310, 641-644.}


South African Committee for Stratigraphy, 1980. Chapter 2.3: The Murchison Sequence, In: 559 C.L.E. Hart

1318 (Editor), Stratigraphy of South Africa, part 1: Lithostratigraphy of the 560 Republic of South Africa, South 1319 West Africa/Namibia and the Republics of 561 Bophuthatswana, Transkei and Venda. South Africa Geological 1320 Survey Handbook, 45-562 52.

Stacey, J.S and Kramers, J.D., 1975. Approximation of terrestrial lead isotope evolution by a two-stage model. Earth Planet. Sci. Lett. 26, 2, 207-221

Stüwe, K., 1997. Effective bulk composition change due to cooling: a model predicting complexities in retrograde reaction textures. Contrib. Mineral. Petrol. 129, 43-52.

Tajcmanová, L., Connolly, J.A.D., Cesare, B., 2009. A thermodynamic model for titanium and ferric iron solution in biotite. J. Metamorph. Geol. 27, 153-64.

Van Kranendonk, M.J., Hickman, A.H., Smithies, R.H., Nelson, D.N., Pike, G., 2002. Geology and tectonic evolution of the Archaean North Pilbara terrain, Pilbara Craton, Western Australia. Econ. Geol. $97,695-732$.

Vearncombe, J.R., Barton, J.M. and Walsh, K.L. (1987). The Rooiwater Complex and associated rocks, Murchison granitoid-greenstone terrane, Kaapvaal Craton. S. Afr. J. Geol., 90, 361-377.

Vearncombe, J. R., Cheshire, P. E., De Beer, J. H., Killick, A. M., Mallinson, W. S., McCourt, S., et al., 1988a. Structures related to the Antimony line, Murchison schist belt, Kaapvaal craton, South Africa. Tectonophysics, 154 (3-4), 285-308. 
Vearncombe, J. R., 1988b. Structure and metamorphism of the Archean Murchison Belt, Kaapvaal Craton, South Africa. Tectonics, 7(4), 761-774.

Vearncombe, J. R., Barton, J. M., Cheshire, P. E., De Beer, J. H., Stettler, E. H., and Brandl, G., 1992. Geology, geophysics and mineralization of the Murchison Schist Belt, Rooiwater Complex and surrounding granitoids, Memoir of the Geological Survey of South Africa, 81, 139p.

Volodichev, O., Slabunov, A., Bibikova, E., Konilov, A., Kuzenko, T., 2004. Archean eclogites in the Belomorian mobile belt, Baltic Shield. Petrology, 12, 540-560.

Waldbaum, D.R., Thompson, J.B., 1968. Mixing Properties Of Sanidine Crystalline Solutions .2. Calculations Based On Volume Data. Am. Min. 53, 2000-?

Watts, A.B. and Burov, E.B., 2003. Lithospheric strength and its relationship to the elastic and seismogenic layer thickness. Earth Planet. Sci. Lett. 213, 113-131.

White, R.W., Powell, R., Holland, T.J.B., Worley, B.A. 2000b. The effect of $\mathrm{TiO}_{2}$ and $\mathrm{Fe}_{2} \mathrm{O}_{3}$ on metapelitic assemblages at greenschist and amphibolite facies conditions: mineral equilibria calculations in the system $\mathrm{K}_{2} \mathrm{O}-\mathrm{FeO}-\mathrm{MgO}-\mathrm{Al}_{2} \mathrm{O}_{3}-\mathrm{SiO}_{2}-\mathrm{H}_{2} \mathrm{O}-\mathrm{TiO}_{2} \mathrm{Fe}_{2} \mathrm{O}_{3}$. J. Metamorph. Geol. 18:497-511. 
Zeh, A., 2001. Inference of a detailed P-T path from P-T pseudosections using metapelitic rocks of variable composition from a single outcrop, Shackleton Range, Antarctica. J. Metamorph. Geol., 19, 329-350.

Zeh, A., Klemd, R., Buhlmann, S., Barton J.M., 2004. Pro- and retrograde P-T evolution of granulites of the Beit Bridge Complex (Limpopo Belt, South Africa): constraints from quantitative phase diagrams and geotectonic implications. J. Metamorph. Geol., 22, 79-95.

Zeh, A., 2006. Calculation of garnet fractionation in natural metamorphic rocks, with application to a flattop, Y-rich garnet population from the Ruhla Crystalline Complex, Central Germany. J. Petrol., 47, $2335-2356$.

Zeh, A., Gerdes, A. and Barton, J.M., 2009. Archean Accretion and Crustal Evolution of the Kalahari Craton - the Zircon Age and Hf Isotope Record of Granitic Rocks from Barberton/Swaziland to the Francistown Arc. J. Petrol., 50, 933-966. 